\title{
Suomen arvopohjainen Euroopan unionin puheenjohtajuus 2019
}

ABSTRAKTI Suomi toimi Euroopan unionin neuvoston puheenjohtajamaana vuoden 2019 jälkipuoliskolla. Suomen puheenjohtajuusohjelma oli vahvan arvoperustainen ja korosti EU:n merkitystä ennen kaikkea arvojen yhteisönä. Tässä artikkelissa selvitetään miksi ja mistä arvopainotus tuli Suomen ohjelmaan sekä minkälaista poliittista keskustelua ohjelman laatimiseen liittyi. Tämän jälkeen tarkastellaan yksityiskohtaisemmin arvojen konkreettista toimeenpanoa puheenjohtajuuskaudella. Artikkelin lopuksi arvioidaan arvopainotuksen onnistuneisuutta sekä yksittäisten arvojen kohdalla että laajemmassa merkityksessä. Artikkelin aineistona ovat Suomen puheenjohtajuuskauteen liittyvät asiakirjat sekä tutkimushaastattelut $(\mathrm{N}=33)$, jotka suoritettiin keskeisten suomalaisten poliitikkojen, virkahenkilöiden ja kansalaisjärjestöjen asiantuntijoiden keskuudessa kevään 2020 aikana. Artikkelin mukaan arvot nousivat jo valmisteluvaiheessa puheenjohtajuuden kantavaksi teemaksi, ja kauden lähestyessä niiden painoarvo vahvistui. Suomi myös onnistui edistämään useita EU:n arvoja, erityisesti sitomalla niitä käytännön kysymyksiin. Arvoperustaisuuden onnistuminen on artikkelin mukaan moninainen kysymys, johon on mahdollista tarjota erilaisia vastauksia. 


\section{JOHDANTO}

Erilaiset kriisit nostavat usein keskustelun arvoista politiikan keskiöön. Euroopan unionissa (EU) on käyty viime vuosina paljon arvokeskustelua, erityisesti liittyen demokratian ja oikeusvaltioperiaatteen kunnioittamiseen. On puhuttu jopa laajemmasta EU:n perusarvojen kriisistä. Huolta on herättänyt ensinnäkin se, ettei EU:lla tunnu olevan yksimielisyyttä tai välineitä puuttua joidenkin jäsenmaiden, kuten Puolan ja Unkarin arvorikkomuksiin (Closa ja Kochenov 2016, 4). Toisekseen huoli liittyy siihen, että laajempi perusarvojen horjuminen voi tuottaa syviä normatiivisia jakolinjoja ja heikentää unionin poliittista ja moraalista uskottavuutta (Müller 2016, 207). Keskustelu arvoista on myös politisoitunut, mikä on johtanut kiistelyyn unionin ja jäsenvaltioiden toimivallasta (Furedi 2018). Konkreettisista arvojen kunnioittamista tukevista toimenpiteistä, kuten EU-varojen ehdollistamisesta käytävä vilkas keskustelu korostaa aiheen ajankohtaisuutta.

Suomi toimi EU:n ministerineuvoston puheenjohtajana loppuvuonna 2019. Suomi painotti puheenjohtajuusohjelmassaan EU:n merkitystä arvoyhteisönä sekä erityisesti oikeusvaltioperiaatteen vahvistamista (VNK 2019). Tässä artikkelissa Suomen puheenjohtajuuskautta tarkastellaan arvopainotuksen näkökulmasta. Aluksi tarkastellaan, miten arvot nousivat kauden keskiöön ja millaista keskustelua ohjelman valmisteluun liittyi. Kysymys on mielenkiintoinen, sillä arvojen vahvan korostamisen voidaan nähdä poikkeavan Suomen perinteisesti pragmaattisesta EU-politiikan linjasta. Toiseksi tarkastellaan Suomen toimia yksittäisten EU:n perusarvojen tukemiseksi kauden aikana. Kolmanneksi pohditaan yleisemmin arvoperustaisen painotuksen onnistumista asiantuntijanäkemysten valossa. Artikkeli perustuu laajaan asiakirja-aineistoon sekä puheenjohtajuuskauden kannalta keskeisten toimijoiden, kuten poliitikkojen, virkahenkilöiden ja kansalaisjärjestöjen edustajien, kattavaan haastatteluaineistoon $(\mathrm{N}=33)^{1}$.

Ministerineuvoston puheenjohtajan mahdollisuudet vaikuttaa EU:n politiikkaan on jakanut tutkijoiden mielipiteitä. Puheenjohtajuuksia on tutkittu esimerkiksi vertailevasta näkökulmasta (Elgström 2003), yksittäisten jäsenmaiden rooleja arvioiden (Bunse 2009) sekä kausiin vaikuttavia tekijöitä eritellen (Vandecasteele ja Bossyut 2014). Erityisesti Lissabonin sopimuksen tuomien muutosten jälkeen puheenjohtajuusroolin on katsottu entisestään heikentyneen (Ojanen 2018). Nykyään tehtävät keskittyvät pääosin unionin sisälle, kokousten suunnitteluun ja johtamiseen sekä kommunikointiin EU:n muiden toimielinten kanssa. Artikkelissa tuodaan kuitenkin esiin, kuinka puheenjohtajamaan on mahdollista sekä painottaa haluamiaan teemoja että vaikuttaa niiden käsittelytapaan. Erityisesti pienten valtioiden, kuten Suomen, kohdalla rajatut prioriteetit ja yhtenevyys eurooppalaisten intressien kanssa on tehokas tapa vaikuttaa (Grøn ja Wivel 2011, 529). Kuuden kuukauden puheenjohtajuus on toki lyhyt aika ja se harvoin etenee valmiin käsikirjoituksen mukaisesti. Tämä tekee sekä puheenjohtajan vaikuttamisesta että sen toiminnan arvioinnista haastavaa. Lisäksi arvioinnissa sekoittuvat usein eri näkökulmat sekä vaikutusvallan, menestyksen ja tehokkuuden käsitteet (Ojanen 2018, 11). Tässä artikkelissa Suomen puheenjohtajuuskautta arvioidaan erityisesti sen oman ohjelman tavoitteita vasten.

Artikkelin keskeinen anti on arvoperustaisuuden merkityksen avaamisessa sekä arvojen operationalisoinnin ja vaikutusten arvioinnissa käytännön EU-politiikassa. Lähtökohtana on yksittäisen, pienen jäsenmaan rooli ja erityisesti aiemman tutkimuksen valossa menestyksekkääksi todettu strategia painottaa arvoja ja normeja (Björkdahl 2008). Tutkimus ankkuroituu Suomen 
puheenjohtajuuksien tutkimuksen ohella myös laajempaan puheenjohtajuuksia käsittelevään kirjallisuuteen, joskin sen näkökulma on näistä poikkeava. Suomen puheenjohtajuuksia on tarkasteltu esimerkiksi kausien ohjelmien, painopisteiden sekä taustatekijöiden valossa (Arter 2000; Stubb 2000; Martikainen ja Tiilikainen 2000; Ojanen ja Vuohula 2006). Arvoperustaisuus tarjoaa tuoreen näkökulman, josta käsin Suomen EU-politiikan linjaa ja myös sen mahdollista viiteryhmää EU:ssa voidaan pohtia.

Artikkelin aluksi tarkastellaan ajatusta EU:sta arvojen yhteisönä ja sen kohtaamia haasteita viime vuosina. Tämän jälkeen käydään läpi Suomen arvoperustaisen puheenjohtajuuden taustaa ja lähtökohtia. Artikkelin aineiston ja menetelmän esittelyn jälkeen edetään empiiriseen osaan, jossa tarkastellaan arvojen nousua puheenjohtajuusagendalle, arvojen käytännön toteuttamista kauden aikana sekä Suomen arvopainotuksen arviointia.

\section{EUROOPAN UNIONI ARVOJEN YHTEISÖNÄ}

Arvoperustaisuus viittaa siihen, että arvoilla on olennainen rooli yhteisön jaettuina päämäärinä ja sen toimintaa ohjaavina periaatteina. Yhteisen arvoperustan kunnioittaminen on EU:ssa jäsenyyden ehto. Arvoperustan kunnioittaminen tarkoittaa laajemmin sitä, että EU:n ja sen jäsenmaiden tulisi toimia keskeisten perusarvojen ohjaamana sekä sisä- että ulkopolitiikassaan. Arvot ovat olleet myös tärkeitä eurooppalaisen identiteetin muotoiluissa, joskin ne ovat painottuneet hieman eri tavoin (Risse 2010; Checkel ja Katzenstein 2009). Liberaalit tulkinnat nostavat universaaleiksi tulkitut demokraattiset arvot EU:n keskiöön, kun taas kansallismielisemmät tulkinnat näkevät nämä pikemminkin uhkana kansallisille arvoille (Tuominen ja Nyyssönen 2019). Populismin, nationalismin ja muukalaisvihan nostaessa päätään Euroopassa, yhteisten arvojen vahvistamisesta on toivottu apua eurooppalaisten yhteiskuntien ongelmiin (EU neuvosto 2015). Erityisesti Britannian eroäänestyksen jälkeen perusarvojen ja eurooppalaisen identiteetin vahvistaminen on nostettu esiin keskeisenä EU:ta yhdistävänä tavoitteena. Tätä ilmentää myös Eurooppa-neuvostossa käyty perusteellinen arvo- ja tulevaisuuskeskustelu, jonka tulokset tiivistettiin Rooman julistuksena (Eurooppa-neuvosto 2017).

Julkisesta arvojen alleviivaamisesta huolimatta niiden turvaaminen käytännössä on osoittautunut vaikeaksi (Weatherill 2016, 406). Taustalla piilevät syvät erimielisyydet koskien integraation luonnetta ja EU:n toimivaltaa. Integraation historiaan suhteutettuna arvoyhteisöllisyyden korostaminen on varsin tuore ilmiö, sillä yhteisöjen alkuperäinen tarkoitus liitettiin ensisijaisesti taloudelliseen yhteistyöhön ja vakauden turvaamiseen. Sopimustasolla arvoihin viitattiin varsin niukasti ja valikoidusti. (Weatherill 2016, 393; Williams 2010; Williams 2004.) Yleisemmin arvoja ryhdyttiin tuomaan esiin joidenkin valtioiden ulkopolitiikassa 1970-luvulta lähtien ja kylmän sodan päättyminen kiihdytti tätä kehitystä. (Dunne 2018; Ojanen ja Raik 2017, 175). EU:ssa arvot ovat nousseet esiin erityisesti itälaajentumisen yhteydessä EU:n jäsenyyden ehtoina (Wennerström 2020) sekä EU:n ulkosuhteita ohjaavina periaatteina (Manners 2002; Lucarelli ja Manners 2006; Smith 2018). Luonnehdinnat EU:sta normatiivisena valtana (Manners 2002) korostivat unionin arvoperustaista roolia maailmanpolitiikassa. Roolin uskottavuus edellytti toimia arvoperustaisuuden vahvistamiseksi EU:n sisällä. Taloudelliseen menestykseen perustuvan 
roolin sijaan EU:lle pyrittiinkin luomaan uusi normatiivinen perusta ja oikeutus erityisesti epäonnistuneen perustuslakisopimuksen valmisteluissa (Williams 2010, 7). Lopulta Lissabonin sopimuksessa (2009) arvot asetettiin unionin perustaksi ja niiden edistämisestä tuli unionin keskeinen päämäärä. Loikka talousyhteistyöstä arvoyhteisöllisyyteen oli muutos, jolle on löytynyt myös paljon vastustajia. Erimielisyydet integraation suunnasta ja tavoiteltavista päämääristä ovat kärjistyneet viime vuosien kriisien myötä. Kuten Frank Furedi $(2018,128)$ arvioi, keskustelut arvoyhteisöllisyydestä ja yhteisten arvojen haasteista tulevat säilymään EU:ta jakavina, keskeisinä kysymyksinä tulevaisuudessa.

Keskustelussa yhteisistä arvoista on tehtävä analyyttinen ero laajempien eurooppalaisten kannattamien arvojen ja EU:n sopimustason sekä instituutioiden edistämien arvojen välillä (Foret ja Calligaro 2018, 5). Tässä artikkelissa huomio on nimenomaan EU:n sopimusten ja instituutioiden edustamassa arvopolitiikassa. EU:n perusarvot eli ihmisarvon loukkaamattomuus, vapaus, demokratia, tasa-arvo, oikeusvaltioperiaate ja ihmisoikeuksien kunnioitus, vähemmistöihin kuuluvien oikeudet mukaan luettuina, ovat määritelty Lissabonin sopimuksen (2009) toisessa artiklassa. Lisäksi oikeudellisesti sitova EU:n perusoikeuskirja on olennainen osa EU:n arvoperustaa. Sopimustasolla jäsenvaltioiden yhteiskuntia määritteleviksi periaatteiksi mainitaan lisäksi moniarvoisuus, syrjimättömyys, suvaitsevaisuus, oikeudenmukaisuus, yhteisvastuu sekä naisten ja miesten tasaarvo. EU:n normatiivista perustaa tutkinut Manners $(2006,38)$ päätyy yhdeksään EU:ta ohjaavaan periaatteeseen, joihin lukeutuu edellä mainittujen lisäksi rauha, hyvä hallinto ja kestävä kehitys. Rauha mainitaan Lissabonin sopimuksen kolmannessa artiklassa laajempana EU:n päämääränä, jonka osalta EU:n toimet on tunnustettu Nobelin rauhanpalkinnolla vuonna 2012. Oikeusvaltioperiaatteeseen liittyvä hyvä hallinto taas on kokonaisuus, johon sisältyy muun muassa laillisuuden periaatteen kunnioittaminen, korruptionvastaisuus, avoimuus, läpinäkyvyys, puolueettomuus ja osallisuus. Kestävän kehityksen merkitys on noussut ilmastonmuutoksen vastaisen työn kautta. Perusarvojen ja laajempien periaatteiden tai päämäärien suhde jää silti usein epäselväksi (Foret ja Calligaro 2018, 5). Voitaneen todeta, että useimmat periaatteet ovat myös arvoja, mutta kaikkia arvoja ei ole saatettu oikeudellisiksi normeiksi. Toisaalta arvot ohjaavat toimintaa perustavalla tasolla, kun taas normit ovat enemmänkin välineitä arvojen toteuttamiseksi.

Kaikki EU:n jäsenmaat ovat sitoutuneet arvojen kunnioittamiseen jäsenyytensä myötä ja EUinstituutiot ovat pyrkineet monin tavoin edistämään ja valvomaan arvojen toteutumista. Euroopan parlamentti on nähty keskeisenä arvoja puolustavana instituutiona (Feliu ja Serra 2015, 19), joka on ottanut vahvasti kantaa jäsenmaiden arvorikkomuksiin. Komissiolla taas on tärkeä rooli EU:n arvojen kunnioittamisen vartijana osana perussopimusten noudattamisen valvontaa. EU:n instituutioiden "arvovalvonta" on herättänyt vastustusta kansallisella tasolla. Jäsenmaavetoista arvojen vertaisarviointia EU:n neuvostossa on pidetty hyväksyttävämpänä, joskin astetta heikompana vaihtoehtona arvojen suojelulle (ks. Closa 2016). Arvojen valvonnan välineitä on kehitetty viime vuosina täydentämään artikla seitsemään liittyviä ehkäiseviä (7.1) ja rankaisevia (7.2) toimia. Jäsenyyden ehdollistamisen ohella komissio voi viedä rikkomuksia Unionin tuomioistuimen käsiteltäväksi ja se julkaisee vuosittain jäsenmaiden oikeusalan kehityksen tulostaulua. Vuonna 2014 komissio (EU komissio 2014) ja neuvosto (EU neuvosto 2014) lanseerasivat pehmeämmät oikeusvaltioperiaatemekanismit. Komissio laati myös hiljattain uuden toimintasuunnitelman oikeusvaltioperiaatetoimien lujittamisesta (EU komissio 2019). Näiden ohella eri EU-instituutiot valvovat perusoikeuskirjan oikeuksien toteutumista jäsenmaissa. 


\section{SUOMEN ARVOPERUSTAISEN PUHEENJOHTAJUUDEN LÄHTÖKOHTIA}

Suomessa Eurooppa-politiikkaa hoidetaan hallituksen ja eduskunnan läheisessä vuorovaikutuksessa. Hallituksen tärkeimmät EU-linjaukset valmistellaan ministerivaliokunnassa ja pääministerillä on keskeinen asema politiikan johtamisessa. Ministerivaliokunnan sihteeristönä toimii valtioneuvoston EU-osasto, joka vastaa politiikan yhteensovittamisesta. Eri ministeriöillä ja niiden virkahenkilöillä on toimialakohtainen vastuu asioiden seurannasta ja valmistelusta eri jaostoissa ja ylimmällä tasolla EU-asioiden komiteassa. Suomen pysyvä EU-edustusto on myös olennaisessa roolissa sekä politiikan valmistelussa että täytäntöönpanossa. Eduskunta osallistuu valmisteluun suuren valiokunnan sekä ulkoasiainvaliokunnan kautta, jotka määrittelevät eduskunnan kannat kuultuaan erikoisvaliokuntia. Suomen EU-politiikkaa on ohjannut vahvasti puoluepoliittinen konsensus, vaikka sisäisiä jakolinjoja on esiintynyt. Perussuomalaiset on ainoa yksimielisen kielteisesti integraatioon suhtautuva eduskuntapuolue, muilla puolueilla eriävät näkemykset ovat enemmän asiakohtaisia. (Ojanen ja Raunio 2018; Raunio ja Mattila 2017, 55-56.) Vaikka eripuraisuutta on ollut erityisesti eurokriisin, pakolaiskriisin ja ilmastokysymysten hoidossa, kansallisen yhtenäisyyden on nähty parhaiten edistävän Suomen vaikutusvaltaa EU:ssa (Hyvärinen ja Raunio 2014, 89; Raunio 2016, 233).

Suomea on luonnehdittu integraatioon myönteisesti suhtautuvana ja yhteisiä ratkaisuja edistävänä jäsenmaana. Suomi on monissa kysymyksissä pyrkinyt EU:n ytimeen, toisin kuin esimerkiksi muut Pohjoismaat. (Ojanen ja Raunio 2018.) Suomen EU-jäsenyyden ensisijaisina motiiveina mainitaan usein talous- ja turvallisuusintressit (Tiilikainen 2003a, 106), mutta jäsenyyttä voidaan tulkita myös identiteetti- ja arvovalintana (Raunio ja Tiilikainen 2003; Raunio ja Saari 2017, 19). Suomen EU-poliittisessa linjassa onkin nähtävissä ennen kaikkea maantieteelliseen asemaan liittyvien kysymysten painottaminen (pohjoinen ulottuvuus, Venäjä-suhteet), EU:n ulko- ja turvallisuuspoliittisen toimijuuden vahvistaminen sekä yhteisten sääntöjen ja normien tukeminen. Erityisesti viimeisen vuosikymmenen aikana myös yhteiset arvot ovat olleet näkyvästi esillä hallitusohjelmissa ja valtioneuvoston selonteoissa (VNK 2009; VNK 2013, 19; VNK 2017, 6). Arvojen näkyvyyteen on vaikuttanut ennen kaikkea se, että ilmastoasioiden ja oikeusvaltioperiaatteen merkitys on noussut EU-tasolla. Tämä on edellyttänyt myös Suomelta kannanottoja. Arvoperustaisuuden näkyvyyden osalta vuoden 2019 puheenjohtajuutta voitaneen pitää poikkeuksellisena, sillä siinä arvot nostettiin ensimmäistä kertaa keskeiseen asemaan. Suomi on toki perinteisesti edistänyt pohjoismaisia arvoja, kuten hallinnon avoimuutta, tehokkuutta ja läpinäkyvyyttä, ympäristökysymyksiä, sukupuolten tasa-arvoa sekä sosiaalista ulottuvuutta ja pyrkinyt näyttäytymään näissä edelläkävijänä (ks. Tiilikainen 2003b, 152; Kantola ym. 2020, 7). Arvot ovat kuitenkin jääneet usein maininnoiksi periaatetasolla, eikä niiden käytännön merkitystä ole alleviivattu.

Vaikuttamisen ja näkyvyyden paikkoja Suomelle ovat erityisesti olleet EU:n ministerineuvoston puheenjohtajuudet vuosina 1999, 2006 ja 2019. Kausia yhdistävät monet samankaltaiset teemat, mutta ne on toteutettu varsin erilaisessa tilanteessa olevassa EU:ssa. On selvää, että puheenjohtajan vaikutusmahdollisuudet ovat kiinni useista, siitä itsestään riippumattomista tekijöistä, minkä lisäksi lyhyellä kaudella on ylipäätään vaikeaa tehdä suuria muutoksia. Lisäksi vuoden 2019 puheenjohtajuus oli ensimmäinen Lissabonin sopimuksen tuomien, puheenjohtajan roolia heikentäneiden muutosten jälkeen² (Grøn ja Wivel 2011, 527-528). Puheenjohtajuus 
on nykyään vähemmän EU:n ulkopuolelle näkyvä toimi ja Eurooppa-neuvostolla on keskeinen asema agendan määrittäjänä. EU:n politiikan johdonmukaisuuden tarve on johtanut lisäksi trioohjelmien laatimiseen peräkkäisten puheenjohtajien kesken (Raik 2015; Lewis 2013, 152) sekä kansallisten ohjelmien tiukempaan sidontaan EU:n strategiseen ohjelmaan. Vaikka kansallisen ohjelman merkitys on nyt aiempaa vähäisempi, kiertävä puheenjohtajamaa pystyy nostamaan valitsemiaan teemoja esille ja vaikuttamaan niiden käsittelyyn neuvostossa. Häge (2017) huomioi myös mahdollisuuden käyttää aikataulutukseen liittyvää valtaa päättämällä, miten kauan asioita käsitellään ja missä järjestyksessä.

Ei siis ole täysin kiistatonta, että Lissabonin sopimus olisi vähentänyt puheenjohtajuuden merkitystä. Lissabonin sopimuksen jälkeiset EU:n kriisit ovat kuormittaneet päätöksentekoa ja lisänneet myös puheenjohtajamaiden mahdollisuuksia osallistua kriisien ratkomiseen (Schout 2017). Vandecasteelen ja Bossyutin mukaan (2014) pienet jäsenmaat ovat menestyneet puheenjohtajina, mikäli ne ovat nauttineet hyvästä maineesta ja valmistautuneet huolellisesti. Vaikutusmahdollisuudet liittyvät olennaisesti kykyyn hoitaa käytännön järjestelyt ja neuvottelut eri tahojen kanssa. Integraation politisoituminen ja erilaisten jakolinjojen syveneminen edellyttävät sekä hyviä neuvottelijoita että taitoa löytää kompromisseja. Suomi on saanut mainetta yhteisöllisyyden puolustajana sekä taitavana kompromissien rakentajana (Lewis 2013, 153). Toisaalta Suomi on pyrkinyt välttämään vastakkainasetteluja ja sulautumaan valtavirtaan (Ojanen ja Raunio 2018).

Vuoden 2019 puheenjohtajuus osui EU:n institutionaaliseen taitekohtaan; uuden parlamentin järjestäytyminen ja komission muodostaminen sekä neuvottelut EU:n monivuotisesta rahoituskehyksestä olivat kesken. Lisäksi Britannian lähtö unionista oli merkittävä kauteen sisältynyt kokonaisuus. Suomi pyrki ennakolta vaikuttamaan Eurooppa-neuvoston uuteen strategiseen ohjelmaan vuosille 2019-2024 sekä uuden komission toimintaan ja työohjelmaan (VNK 2017). Suomi linjasi yhteiset tavoitteet Romanian ja Kroatian kanssa joulukuussa 2018 (EU neuvosto 2018). Tosiasiassa Suomi jalkautti jo osin EU:n uuden strategisen ohjelman tavoitteita (Eurooppa-neuvosto 2019). Suomella oli kokonaisuutena vaikeasti haltuun otettava kausi, mutta institutionaalinen välivaihe mahdollisti aidosti poliittisen puheenjohtajuuden - useimmat prosessit olivat auki ja keskustelulle oli tilausta. Tämä tarjosi mahdollisuuden vaikuttaa laajemmin EU:ssa käytävään keskusteluun.

Kauden valmisteluun vaikutti keväällä 2019 käydyt eduskuntavaalit. Vaalien jälkeen järjestäytyneen Antti Rinteen hallitusohjelman Eurooppa-politiikkaa voidaan kuvailla varsin Eurooppa-myönteiseksi (VN 2019, 66-74). Kesäkuussa 2019 julkistetussa kansallisessa puheenjohtajuusohjelmassa (VNK 2019) korostettiin vahvasti EU:n arvoyhteisöllisyyttä sekä Suomen roolia arvojen edistäjänä hallitusohjelman painotuksia mukaillen. Ohjelman ensimmäinen tavoite liittyi yhteisten arvojen ja oikeusvaltioperiaatteen kunnioittamisen vahvistamiseen. Perusarvojen, kuten ihmisarvon, vapauden, kansanvallan, tasa-arvon, oikeusvaltioperiaatteen ja ihmisoikeuksien kunnioittaminen mainitaan keskeisinä EU:n asianmukaisen toiminnan, hyväksyttävyyden ja uskottavuuden kannalta. Toisena tavoitteena oli kilpailukykyinen ja sosiaalisesti eheä EU, joka korostaa sosiaalista oikeudenmukaisuutta, yhteisvastuuta, osallisuutta sekä tasa-arvoa keskeisinä toimintaa ohjaavina periaatteina. Kolmas tavoite pyrki kirkastamaan EU:n asemaa globaalina ilmastojohtajana. Kestävyys oli arvona näkyvästi esillä, jopa ohjelman otsikkotasolla. Ohjelman neljäs tavoite keskittyi kokonaisturvallisuuteen ja nosti vahvasti esiin 
monenvälisyyden tukemisen. Lisäksi ohjelma linjasi muista kauden keskeisistä asioista, kuten maahanmuutosta ja monivuotisen rahoituskehyksen valmistelusta, joissa molemmissa arvopainotus oli esillä. Kokonaisuutena ohjelma heijasteli "henkistä muutosta" hallituksen EU-politiikassa sekä sosiaalisten ja ympäristöllisten arvojen vahvempaa painotusta mukana olevien puolueiden näkemyksiä mukaillen.

\section{AINEISTO JA MENETELMÄ}

Tämän artikkelin tutkimusaineisto muodostuu puheenjohtajuuskauteen liittyvästä asiakirjaaineistosta ja laajasta, pj-kauden kannalta keskeisten toimijoiden haastatteluaineistosta $(\mathrm{N}=33)$. Asiakirja-aineisto sisältää puheenjohtajuuskauden valmisteluun liittyviä asiakirjoja, kuten kokousmuistioita (suuri valiokunta, MINVA), hallitusohjelmia, eduskunnan täysistuntotallenteita, hallitusneuvotteluasiakirjoja, puheenjohtajuuskaudella painotettavien teemojen taustoituspapereita ja raportteja. Lisäksi aineistona on hyödynnetty eri toimijoiden lausuntoja, neuvoston päätöslauselmia, konferenssien loppuasiakirjoja sekä Suomen virallisia puheenjohtajuuskauden verkkosivustoja (eu2019.fi). Asiakirjat ovat julkisia ja ne on kerätty eri toimijoiden verkkosivuilta. Asiakirjoihin viitataan muodossa "toimija, vuosi" (esim. VN 2019) ja vain viitatut asiakirjat on sisällytetty lähdeluetteloon.

Haastattelut täydentävät asiakirjoista saatua virallista kuvaa ja niiden käyttö on perusteltua, sillä puheenjohtajuus sisältää paljon hiljaista diplomatiaa ja valmistelutyötä epävirallisissa yhteyksissä (Lewis 2013, 152). Koska artikkeli keskittyy kansalliseen näkökulmaan ja asiakirjoihin, myös haastateltavat edustavat kansallisia tahoja. Haastateltavat valikoituivat asiantuntijuutensa perusteella, joka liittyi heidän institutionaaliseen asemaansa ja tehtävänkuvaansa (ks. Alastalo ym. 2017). Poliitikoista (10 kpl) haastateltiin suuren valiokunnan EU-puheenjohtajuusohjelmaa valmistelleita työjaoston jäseniä sekä valiokunnan puheenjohtajistoa. Näiden ohella haastateltiin puheenjohtajuuskautta edeltävää (Juha Sipilä) ja puheenjohtajuuskauden pääministeriä (Antti Rinne) sekä vastaavia eurooppaministereitä (Sampo Terho ja Tytti Tuppurainen). Haastatellut virkahenkilöt (9 haastattelua) edustivat eduskunnan EU-työtä, valtioneuvoston EU-osastoa, eri ministeriöiden EU-asiantuntijoita sekä Suomen EU-edustustoa. Virallisempia tahoja täydentävät kansalaisjärjestöjen asiantuntijoiden haastattelut (14 kpl). Kansalaisjärjestöt valikoituivat tutkimukseen osallistumisen perusteella (kuulemiset, lausunnot) sekä arvokohtaisesti (toimialakohtaisuus). Haastateltaville on luvattu anonymiteetti, joten näkemyksiä hyödynnetään tekstissä toimijakohtaisesti (viittaukset esim. haastattelu poliitikko=POL, virkahenkilö=VIR ja kansalaisjärjestö=KAN). Aihepiirin arkaluontoisuus ja haastateltavien helppo tunnistettavuus perustelevat anonymiteetin käyttöä, jonka moni osallistujista koki tärkeänä. Lista haastatelluista aakkosjärjestyksessä löytyy artikkelin liitteestä.

Valtaosa haastatteluista tehtiin puhelimitse kevään 2020 aikana COVID-19 -tilanteesta johtuen. Haastattelunauhoitteet tai -muistiinpanot ovat kirjoittajan hallussa. Artikkelin käsikirjoitusversio lähetettiin kaikille haastatelluille kommentoitavaksi ennen julkaisua. ${ }^{4}$ Tämän voi nähdä edelleen täydentävän faktakuvausta prosessista (Alastalo ja Åkerman 2010, 390). Puolistrukturoitujen haastattelujen sisällöllisenä lähtökohtana olivat EU:n perussopimuksen toisen 
artiklan määrittämät arvot. Haastattelukysymykset liittyivät arvojen asemaan puheenjohtajuuskauden valmistelussa, arvokysymysten näkyvyyteen kauden aikana sekä arvoperustaisen ohjelman onnistumisen arviointiin. Haastatteluja edelsi yksityiskohtaisempi tutustuminen asiakirjoihin ja haastateltavan asemaan prosessissa. Haastatteluteemat painottuivat näin hieman sen mukaan, mihin edellä mainituista toimijaryhmistä haastateltava kuului ja tarkemmat kysymykset räätälöitiin haastateltavan roolin mukaisesti (kysymysten eriyttämisestä ks. Alastalo ja Åkerman 2010, 378). Kauden valmistelun osalta poliitikkojen ja virkahenkilöiden haastattelut ovat keskiössä, kansalaisjärjestöjen edustajien näkemykset taas painottuvat arvoperustaisuuden arvioinnissa.

Aineistoa analysoidaan laadullisen sisällönanalyysin avulla, jossa keskeistä on erilaisten kategorioiden muotoilu suhteessa tutkimuksen kolmeen pääteemaan. Moniaineistoisessa tutkimusprosessissa faktuaalisen luennan varmistamiseksi huomiota on kiinnitetty lähteiden kriittiseen ristiinluentaan sekä siihen, miten eri lähteet koettelevat toisiaan (Alastalo ja Åkerman 2010). Haastattelujen analyysissa on kiinnitetty huomiota myös kontekstuaalisuuteen. Ensinnäkin poliitikkojen osalta puoluesidonnaisuus ja hallitus-oppositio-asetelma voi vaikuttaa esitettyjen näkemysten taustalla. Toisekseen, osa haastatelluista arvioi suoraan omaa työtään, osalla taas suhde puheenjohtajuuskauteen oli riippumattomampi. Näin ollen jotkut haastatellut, erityisesti poliitikot, voivat jopa yliarvioida Suomen vaikutusta. Kansalaisjärjestöjen tulkinnat lienevät virallista tasoa kriittisempiä ja asiakohtaisempia. Kolmanneksi, tarkempi päätöksenteon taustan ja Suomen mahdollisuuksien ymmärtäminen voi johtaa realistisempaan arvioon Suomen puheenjohtajuuskauden mahdollisuuksista. Analyysissa huomiota on kohdistettu erityisesti eri toimijaryhmien antamien kuvausten ja tulkintojen välisiin eroihin ja jännitteisiin.

\section{MIKSI JA MISTÄ ARVOPERUSTAISUUS TULI PUHEENJOHTAJUUSKAUDEN OHJELMAAN?}

Ensimmäisenä tutkimuksen tavoitteena oli selvittää arvojen nousua Suomen puheenjohtajuuskauden keskiöön. Tyypillisesti jäsenmaan puheenjohtajuusvalmistelut käynnistyvät noin 18 kuukautta ennen kauden alkua (Lewis 2013, 152). Suomen osalta valmisteluiden voidaan katsoa käynnistyneen alkuvuodesta 2018 ja toimintaa ohjasi Valtioneuvoston EU-vaikuttamisstrategia (VNK 2017). Arvoperustaisuuden lähtökohtien osalta huomio jakaantuu toisaalta poliittiseen prosessiin, toisaalta taas virkahenkilöiden valmistelutyöhön: Miten arvot näkyivät puolueiden painotuksissa, puheenjohtajuuskautta koskevissa neuvotteluissa ja sen virkavalmistelussa? Entä vaikuttiko epävirallisempi kansalaisjärjestöjen kampanjointi ohjelman arvosisältöihin?

Kansallisesta puheenjohtajuusohjelmasta aloitettiin parlamentaariset keskustelut hallitus- ja oppositiopuolueiden kesken pääministerin Sipilän johdolla maaliskuussa 2018. Eduskuntaryhmien näkemyksiä työstettiin suuren valiokunnan työryhmässä ja ne julkaistiin lokakuussa 2018 (Eduskunta 2018a). Haastateltujen poliitikkojen mukaan yhteisten arvojen tärkeys nousi esille raportin valmistelussa puoluerajoista riippumatta. Suomen perinteisenä linjana ja intressinä pienenä maana nähtiin laajalti olevan kansainvälisten instituutioiden, niiden sääntöjen ja YK:n yleismaailmallisten arvojen puolustaminen. Arvopainotukseen haastateltavat tarjosivat erilaisia 
selityksiä. Valtaosan puolueista mainittiin kantaneen huolta EU:n arvopohjan rapautumisesta. Suuressa valiokunnassa Puolan tilannetta oli käsitelty paljon ja yleinen turhautuneisuus toimien riittämättömyydestä lisäsi arvoteemojen pohdintaa. Toisaalta poliitikot mainitsivat haastatteluissaan yleisesti laajemman maailmanpoliittisen tilanteen ja huolen Brexitistä, Donald Trumpin politiikasta ja liberaalin demokratian sekä sääntöperustaisuuden tulevaisuudesta. Eduskuntatyöryhmän raportti ilmentää silti puolueiden erilaisia lähtökohtia ja intressejä EU-politiikassa. Siihen sisällytettiinkin merkintä, etteivät kirjaukset välttämättä edusta kaikkien eduskuntaryhmien kantoja.

Toinen poliitikkojen haastatteluissa esiinnoussut puheenjohtajuuskauteen vaikuttanut paperi oli joulukuussa 2018 julkaistu kahdeksan puolueen ilmastolinjaus, jonka mukaan Suomi ajaisi puheenjohtajana nykyistä kovempia päästöleikkauksia. Perussuomalaiset irtisanoutuivat ilmastolinjauksesta loppumetreillä. Ilmastokysymykset olivat myös pääministeri Sipilän agendalla hänen tavatessaan jäsenmaiden johtajia ennen puheenjohtajuuskautta (Sipilä 2019). Suomi ei kuitenkaan allekirjoittanut tiukempia päästövähennyksiä vaativaa yhdeksän jäsenmaan kirjettä toukokuussa 2019 vedoten tulevan puheenjohtajuutensa edellyttämään neutraaliuteen (Raivio ja Stenroos 2019). Toiset haastatelluista politiikoista näkivätkin linjauksen merkityksen kasvaneen vasta hallitusneuvotteluvaiheessa.

Joulukuussa 2018 eduskunnan täysistunnossa käytiin keskustelu EU:n tulevasta kehityksestä ja Suomen puheenjohtajuuskauden teemoista (Eduskunta 2018b). Keskustelussa kiiteltiin parlamentaarista valmistelutyötä ja korostettiin kansallisen yhtenäisyyden merkitystä, vaikka jännitteitä ilmeni eurooppa- ja kansallismielisten näkemysten välillä. Vastaava jännite on heijastunut kansallisessa EU-keskustelussa laajemminkin viimeisen vuosikymmenen aikana (Raunio ja Saari 2017; Ojanen ja Raunio 2018). Ennen kaikkea perussuomalaisten ja osin sinisten näkökulmasta ohjelma oli liian integraatiomyönteinen ja maahanmuutto koettiin vaikeana aiheena. Haastatteluissa ilmeni poliitikkojen laaja tuki arvoperustaiselle lähestymistavalle, mutta täysistuntokeskustelun tavoin osa poliitikoista olisi toivonut kansallisille hankkeille enemmän näkyvyyttä. Haastatteluissa korostettiin silti laajalti prosessissa vallinnutta hyvää yhteistyöhenkeä erimielisyyksistä huolimatta.

Suomen puheenjohtajuuden valmistelu ministeriöissä oli pidemmän aikavälin työtä, johon liittyi myös uuteen Eurooppa-neuvoston strategiseen ohjelmaan vaikuttaminen. Suomi ajoi strategiaan erityisesti yhteisiä arvoja, ilmastokysymyksiä, turvallisuutta ja kasvua (VN 2019b). Virkavalmisteluun kuului neuvoston työohjelman ennakointi ja aiheiden listaaminen sekä tapahtumien suunnittelu eri ministeriöiden toimialoilla. Vastuu trio-ohjelmasta oli myös valtioneuvoston kanslialla ja ohjelma esiteltiin yleisten asioiden neuvostossa joulukuussa 2018. Haastateltujen virkahenkilöiden mukaan valmistelussa edettiin Sipilän hallituksen Eurooppa-poliittisten linjausten mukaisesti ja tässä arvot eivät olleet keskeisessä asemassa. Myöskään ministerivaliokunnan keskusteluissa arvojen ei koettu ainakaan sanallisesti nousseen merkittävään rooliin. Toisaalta osassa haastatteluista nostettiin, ehkä hieman yllättäen, esiin Suomen pitkän linjan pyrkimys arvojen puolustajana. Lisäksi niin poliitikkojen kuin virkahenkilöidenkin haastatteluissa tuotiin esiin Suomen perinteisesti pragmaattista linjaa valmistautumisessa sekä yleisemmän asialistan kehittymisen vaikutuksia. Arvojen osalta vaikutus oli kahtalainen - EU-instituutioissa käydyn arvopuheen nähtiin vaikuttaneen olennaisesti Suomen ohjelmaan. Ajoitus koettiin suotuisana erityisesti oikeusvaltioperiaatteen osalta ja virkahenkilöt panostivat lopulta merkittävästi tähän 
teemaan. Toisaalta poliitikot ja virkahenkilöt korostivat Suomen omaa päättäväisyyttä sen ottaessa käsittelyyn arvolatautuneita teemoja, joita aiemmat puheenjohtajat olivat vältelleet komission pyynnöistä huolimatta. Jotkut haastateltavista huomioivat myös Suomen pragmaattisuutta ja sellaisten pyrkimysten laittamista sivuun, joilla ei nähty olevan onnistumisen mahdollisuuksia.

Hallitusneuvotteluissa puolueilta pyydettiin näkemyksiä Suomen puheenjohtajuuskauden keskeisistä tavoitteista. Lisäksi ministeriöt vastasivat kootusti hallitustunnustelija Antti Rinteen kysymyksiin. (VN 2019c.) Eurooppa-poliittisen työryhmän työtä pohjusti eduskuntaryhmien raportti, Valtioneuvoston kanslian virkavalmisteluna laadittu asiakirja sekä puolueiden omat puheenjohtajuuskauden tavoitteet. Poliitikkojen haastatteluissa ilmeni puolueiden eriasteinen valmistautuminen sekä erilaiset näkemykset lopullisen ohjelman muodostumisesta. Virkakunnan paperin nähtiin korostaneen aiemman hallituksen poliittisia, haastatteluissa jopa arvonihilistisiksi kuvattuja linjauksia. Lisäksi turvallisuus tuli ohjelmaan ennalta annettuna tavoitteena. Toisaalta haastateltavat korostivat poliittisen keskustelun käsitelleen varsin laajaa ja kokonaisvaltaista eurooppapoliittista agendaa sekä arvokysymyksiä. Yleisesti ottaen poliitikkojen haastatteluissa korostettiin kärkiteemasta eli oikeusvaltioperiaatteen puolustamisesta saavutettua sopua. Sosiaalinen ulottuvuus sen sijaan koettiin enemmän jakavana teemana. Virkakunta sen sijaan painotti ohjelman valmistelussa vallinnutta EU-poliittista jatkumoa ja suunnitelmanmukaisuutta. Lopullinen puheenjohtajuuskauden ohjelma julkaistiin kesäkuussa 2019 ja puolueiden työryhmän raporttiin verrattuna arvot ja sosiaaliset kysymykset painottuivat siinä vahvemmin uusien hallituspuolueiden tavoitteiden mukaisesti. Ohjelman neljäksi keskeiseksi teemaksi muodostuivat yhteisten arvojen ja oikeusvaltioperiaatteen edistäminen, kilpailukykyinen ja sosiaalisesti eheä EU, EU:n asema globaalina ilmastojohtajana sekä kansalaisten kokonaisturvallisuuden takaaminen (VNK 2019).

Tutkimukseen haastatellut kansalaisjärjestöt olivat varsin yksimielisiä siitä, että kansallisen ohjelman valmisteluun vaikuttaminen oli haasteellista. Erityisen vaikeaksi koettiin vaikuttaminen tasa-arvo- ja yhdenvertaisuuskysymyksien osalta. Näiden teemojen nostaminen puheenjohtajuuskauden keskiöön Sipilän hallituksen aikana oli työlästä Suomen virallisista linjauksista huolimatta. Erilaisia kansalaisjärjestökuulemisia leimasi pidättyvyys, koska tulevasta hallituspohjasta ei ollut tietoa. Haastateltavat nostivat esiin pallottelun eri tahojen välillä, aikataulujen epäselvyyden sekä vaikuttamisen nimellisyyden. Eduskuntatyöryhmän raportin pohjalta järjestettiin lokakuussa 2018 kuuleminen, mutta se koettiin enemmänkin symbolisena kohteliaisuuseleenä. Kuulemiseen osallistui melko vähän järjestöjä ja niiden valikoituminen herätti järjestöissä hämmennystä. Haastatellut poliitikot vahvistivat kansalaisjärjestöjen tulkinnan siltä osin, että ohjelman laatimisessa vältettiin yksityiskohtaisempia intressejä. Järjestöt pyrkivät vaikuttamaan eduskuntavaalien alla suoraan puolueisiin sekä asiantuntijakuulemisten kautta. Heinäkuussa 2019 useat järjestöt reagoivat vielä lopulliseen puheenjohtajuuskauden ohjelmaan julkaisemalla näkemyksiään ja toiveitaan.

Kansalaisjärjestövaikuttamista tapahtui eniten virkavalmistelussa eri työryhmissä ja suorilla yhteyksillä ministeriöihin. Tämän koettiin eriarvoistaneen osallistumista, sillä järjestöjen resurssit ovat varsin erilaisia. Osa järjestöistä toimii jäseninä ministeriöiden valmistelujaostoissa, jolloin niillä on etuoikeutettu asema tiedonsaantiin. Joissain haastatteluissa mainittiin myös henkilösuhteiden vaikuttaneen äänen esille saamiseen. Lisäksi järjestöjen osallisuuteen vaikuttivat niiden eurooppalaiset kattojärjestöt, jotka julkaisivat omat tavoitteensa ${ }^{3}$. Useissa haastatteluissa 
nostettiin esiin Suomen avoimuus kansalaisjärjestövaikuttamiselle ja erään haastateltavan mukaan Suomi olisi ollut jopa ensimmäinen puheenjohtaja, joka järjesti ennen kauttaan tilaisuuden kansalaisjärjestöille Brysselissä. Yhteenvetona voitaneen todeta, että järjestöillä oli mahdollisuuksia ja kykyjä vaikuttaa niille tärkeiden arvojen esiintuomiseen, mutta pääosin tämä tapahtui epäsuorasti virkavalmistelussa.

\section{ARVOJEN TOTEUTTAMINEN PUHEENJOHTAJUUSKAUDEN AIKANA}

Artikkelin tässä osassa käydään läpi EU:n perusarvojen edistämistä Suomen puheenjohtajuuskaudella. Kuvauksessa edetään arvokohtaisesti esitellen konkreettisia toimia arvojen tukemiseksi. Aluksi keskitytään Suomen kärkiteemaan oikeusvaltioperiaatteeseen, johon yhdistetään demokratia ja rauha. Tämän jälkeen käydään läpi sekä perus- ja ihmisoikeuksia että tasa-arvoa ja laajempia vähemmistökysymyksiä. Lopuksi tarkastellaan kestävää kehitystä yhdistettynä sosiaaliseen oikeudenmukaisuuteen. Esitetyt näkemykset perustuvat puheenjohtajuuskauden asiakirjoihin sekä haastateltujen poliitikkojen, virkahenkilöiden ja kansalaisjärjestöjen esittämiin huomioihin.

\section{Oikeusvaltioperiaate, demokratia ja rauha}

Oikeusvaltioperiaate oli arvoista näkyvimmin esillä puheenjohtajuuskaudella ja se nostettiin arvioissa Suomen keskeisimmäksi profiloitumisteemaksi. Arvoperustaisuus tulkittiin useissa haastatteluissa pääosin oikeusvaltioperiaatteen kautta. Eri arvojen sitominen nimenomaan oikeusvaltioperiaatteeseen on näkynyt myös tutkimuskirjallisuudessa ja muissa kansainvälisissä organisaatioissa, kuten Euroopan neuvostossa ja YK:ssa (Magen 2016, 1058). Oikeusvaltioperiaate luetaan asiakirjoissa ja puheissa keskeiseksi osaksi demokraattista yhteiskuntaa ja perusoikeuksia, joten arvoja ei välttämättä eritellä. Vaikka oikeusvaltioperiaate oli ollut EU:ssa pinnalla pitkään, haastateltujen poliitikkojen ja virkahenkilöiden mukaan Suomi edisti asiaa näkyvästi ensimmäisenä puheenjohtajana. Monet aiemmat puheenjohtajamaat ( $\mathrm{mm}$. Romania, Itävalta) olivat olleet haluttomia tarttumaan aiheeseen. Oikeusvaltioperiaate nousi keskeiseksi nimenomaan yleisten asioiden neuvostossa, jossa pidettiin kaksi Unkarin kuulemista, kolme tilannekatsausta Puolasta ja lisäksi kaksi yleisempää keskustelua oikeusvaltioperiaatevälineiden kehittämisestä. Näihin liittyi myös vuosittaisen ministeritason oikeusvaltioperiaatekeskustelun kehittäminen laajemmaksi kokonaisuudeksi, yhdessä komission tulevan vuosiraportin kanssa (VNK 2020). Päätelmät vuosikeskustelun uudistamisesta saivat 26 jäsenvaltion tuen, Unkarin ja Puolan vastustaessa niitä. Pysyvien edustajien komiteassa oikeusvaltioperiaateteema oli myös usein agendalla ja oikeusministerit keskustelivat ensimmäistä kertaa roolistaan oikeusvaltioperiaatteen edistämisessä.

Haastateltujen poliitikkojen ja virkahenkilöiden mukaan Suomen tavoitteena oli edistää oikeusvaltioperiaatteesta käytävää keskustelua rakentavasti ja jäsenmaita yhdistävällä tavalla. Toisinaan aiheen sensitiivisyyden kuitenkin koettiin luoneen jännitteitä kokoustunnelmaan. 
Toisaalta haastatellut mainitsivat usean jäsenmaan ilmaiseen neuvostossa tyytyväisyyttään Suomen aloitteesta. Lähtökohtaisena oletuksena ei haastateltavien mukaan ollut, että Suomi kykenisi muuttamaan yksittäisten maiden käyttäytymistä. Vipuvartena Suomi edisti erityisesti oikeusvaltioperiaatteen kunnioittamista ehtona EU-rahoitukselle osana monivuotista rahoituskehystä, komission ehdotuksen (EU komissio 2018) mukaisesti. Toimet korruption ja petosten torjunnassa sekä hybridiuhkiin varautumisessa liittyivät läheisesti oikeusvaltioperiaatteeseen. Suomi edisti osaltaan Euroopan syyttäjäviraston (EPPO) toiminnan käynnistämistä petosten torjunnan ja unionin varojen käytön valvomiseksi. Suomen kaudella saavutettiin myös yhteisymmärrys säädöskokonaisuudesta, jolla helpotetaan veropetosten havaitsemista etenkin rajat ylittävässä verkkokaupassa (VNK 2020). Hybridiuhkien torjuntaa käsiteltiin eri ministeritason kokouksissa ja joulukuussa hyväksyttiin päätelmät yhteisestä lähestymistavasta (Marin 2019). Suomen kaudella perustettiin myös neuvoston työryhmä koordinoimaan hybridiuhkien torjuntaa. Kärkiteemaksi se ei kuitenkaan noussut odotetulla tavalla (ks. Ojanen 2018, 9). Syyskuussa järjestetyssä konferenssissa käsiteltiin eurooppalaisten yhteiskuntien resilienssiä ja perusarvoja, erityisesti disinformaation ja vaalivaikuttamisen teemojen kautta.

Oikeusvaltioperiaatetta ja perusoikeuksia käsiteltiin haastateltavien poliitikkojen ja virkahenkilöiden mukaan laajasti lisäksi jäsenmaiden parlamenttien EU-politiikasta vastaavien toimijoiden COSAC-konferenssissa. Vaikka pääpaino oli EU:n sisäisessä kehityksessä, Suomi pyrki edistämään oikeusvaltioperiaatetta ja demokratiaa myös ulkosuhteissa. Lokakuussa hyväksyttiin neuvoston päätelmät demokratiasta (EU neuvosto 2019), joissa uudistettiin sitoumus demokratian edistämisestä ulkosuhteissa. Kansalaisjärjestöjen haastatteluissa nostettiin esiin Suomen, erityisesti ministeri Pekka Haaviston aktiivinen rooli asiassa. Lisäksi Suomi edisti kokonaisvaltaista, arvoperustaista yhteistyötä Afrikan kanssa EU-Afrikka-strategian valmistelussa. Suomen kaudella hyväksyttiin myös päätelmät humanitaarisesta avusta ja oikeudesta. Laajentumisen osalta Suomen kaudella ei päästy avaamaan jäsenyysneuvotteluja Pohjois-Makedonian ja Albanian kanssa, joka koettiin pettymyksenä. Suomi on suhtautunut laajentumiseen varsin myötämielisesti (Ojanen 2018, 9), tosin sen toimintamahdollisuudet yksimielisyyttä edellyttävässä asiassa ovat varsin rajalliset.

\section{Perus-ja ihmisoikeudet}

Antti Rinteen (ja Sanna Marinin) hallitusohjelma oli varsin ihmisoikeusmyönteinen ja haastatteluissa tuotiin esiin laajemminkin Suomen profiloitumista perusoikeusmyönteisenä jäsenmaana. Suomi antoi puheenjohtajuuskaudellaan nostetta useille perusoikeusteemoille kansainvälisten konferenssien ja seminaarien muodossa, joista mainittakoon esimerkiksi perusoikeuskirjan 10-vuotisjuhlaseminaari Brysselissä marraskuussa. Ihmisoikeuksien edistämisessä keskeinen keino on ihmisoikeuspuolustajien tukeminen. Suomi kutsui virallisiin ja epävirallisiin kokouksiin mukaan kansallisia ihmisoikeusinstituutioita, tasa-arvoelimiä, eurooppalaisten kansalaisjärjestöjen katto-organisaatioiden edustajia sekä yksittäisiä ihmisoikeuspuolustajia. Ihmisoikeuspuolustajien huomioiminen sai kiitosta kansalaisjärjestöiltä, sillä se oli ollut valmistelussa esillä ollut tavoite. Suomen toivottiin luovan toimivia käytänteitä ihmisoikeuspuolustajien osallistamiseen neuvoston eri kokoonpanoissa. (Amnesty 2018.) Yksittäisinä esimerkkeinä kansalaisjärjestöjen 
edustajien haastatteluissa nostettiin esiin lounastapaaminen ulkoministerikokouksen yhteydessä sekä neuvoston ihmisoikeustyöryhmän (COHOM) kokouksessa. Yksittäisten ihmisoikeuspuolustajien kuulemisten kautta Suomi edisti myös arkaluontoisempia teemoja, kuten seksuaalivähemmistöjen ja vammaisten oikeuksia. Lisäksi EU:n perusoikeusvirasto (FRA) oli aktiivisesti mukana sekä virallisissa tapaamisissa, että lukuisissa epävirallisissa konferensseissa ja keskusteluissa.

Muutama virkakuntaan kuuluvista haastateltavista toi esiin Euroopan neuvoston ja EU:n neuvoston puheenjohtajuuksien tuomat synergiaedut virkatyössä ja verkostojen luomisessa. Suomen kaudella saavutettiin päivitetyt ohjeet EU:n liittymisestä Euroopan ihmisoikeussopimukseen, joka on ollut Suomen pitkäaikaisena tavoitteena. Neuvoston työryhmissä onnistuttiin myös neuvottelemaan kaikkien jäsenvaltioiden tuki neuvoston päätelmille perusoikeuskirjan täytäntöönpanemisesta ja konkreettista jatkotoimista. Lisäksi käytiin keskusteluja haasteista perusoikeuksien alalla, kuten syrjinnästä ja vihapuheesta. Sanan- ja lehdistönvapaus oli korostetusti esillä sekä Eurooppa-neuvostossa että yleisten asioiden neuvostossa erityisesti liittyen Unkarin oikeusvaltioperiaatekuulemisiin. Suomi piti esillä median vapauden ja monimuotoisuuden tärkeyttä sekä toimittajiin kohdistuneita uhkia.

Kansalaisjärjestöt nostivat esiin yritysvastuun kysymykset ja veronkierron sekä haitallisen verokilpailun ja verosuunnittelun ehkäiseminen. Rinteen (ja Marinin) hallitusohjelmassa teemat ovat vahvasti esillä (VN 2019a, liite 5). Lisäksi ohjelmassa on sitouduttu valmistelemaan ihmisoikeuksia koskevaa kansallista yritysvastuulakia (emt., 108) sekä edistämään asioita EUtasolla. Työ- ja elinkeinoministeriö sekä ulkoministeriö järjestivät kansalaisjärjestöjen mukaan varsin onnistuneen yritysvastuukonferenssin Brysselissä joulukuun alussa. Konferenssin loppupäätelmät sisälsivät yli 20 toimenpide-ehdotusta perustaksi EU:n yritysvastuun toimintasuunnitelmalle (UM 2019). Lisäksi Suomi pyrki edistämään julkista maakohtaista veroraportointia (CBCR) suuryrityksille useissa neuvoston kokoonpanoissa, mutta jäsenmaiden erimielisyyksistä johtuen tavoite jäi saavuttamatta.

\section{Sukupuolten tasa-arvo ja vähemmistökysymykset}

Rinteen (ja Marinin) hallitusohjelmassa luvataan vahvistaa EU-tason tasa-arvotyötä muun muassa talousarvion ja naisiin kohdistuvan väkivallan osalta. Ohjelma sisältää myös lupauksen syrjimättömyydestä ja kaikkien osallisuudesta. (VN 2019a, 11, 71.) Ehkä hieman yllättäen puheenjohtajuusohjelmassa sukupuolten tasa-arvo ja vähemmistöjen oikeudet mainitaan varsin suppeasti. Tasa-arvo on esillä yleisenä arvoperustana sekä työelämän ja samapalkkaisuuden kontekstissa, kriisinhallinnassa, kestävässä kehityksessä ja Afrikka-kumppanuudessa (VNK 2019). Naisten ja tyttöjen oikeuksien edistäminen taas on kirjattu läpileikkaavana teemana globaalissa toiminnassa perinteiseen tapaan (ks. Jauhola ja Lyytikäinen 2020, 157). Muita yhdenvertaisuus- ja vähemmistöteemoja ei mainita.

Haastateltavien mukaan puheenjohtajuuskaudella pyrittiin vaikuttamaan sukupuolten tasaarvon valtavirtaistamiseen ja erilaisiin erityistoimiin. Valtavirtaistamisen on nähty epäonnistuneen EU:ssa erityisesti talouspolitiikan ja talouskuripolitiikan kontekstissa (Elomäki ja Kantola 2020, 40). Ylipäätään politiikan taloudellistuminen on muuttanut tasa-arvopolitiikan mahdollisuuksia. Suomen, Romanian ja Kroatian yhteisessä tasa-arvojulistuksessa (STM 2019) yhdistäviä 
teemoja olivat nimenomaan talous, työllisyys ja samapalkkaisuuskysymykset. Julistusta kiiteltiin intersektionaalisuuden mainitsemisesta, joka auttaa pureutumaan tasa-arvopolitiikassa vallitseviin normeihin ja hiljaisuuksiin (ks. Kantola ym. 2020, 19). Intersektionaalisuusteema näkyi myöhemmin myös hallituksen tasa-arvo-ohjelmassa (VN 2020). Syyskuun korkean tason konferenssissa keskityttiin EU:n tulevaisuuden tasa-arvopolitiikan toimintalinjoihin, tasa-arvon ja talouden suhteeseen sekä sukupuolitietoiseen budjetointiin. Ministeri Tuppurainen vaati myös selvityksen EU:n tilintarkastustuomioistuimelta koskien sukupuolten huomiointia EU:n budjetissa. Suomi edisti tasa-arvoa innovatiivisesti osana hyvinvointitaloutta, josta hyväksyttiin päätelmät lokakuun neuvostossa. Useamman järjestön yhteistyönä toteutettiin ”Tasa-arvoisen EU:n tekijät"-kampanja, jossa ministerit kertovat omat toimensa tasa-arvon edistämiseksi puheenjohtajuuskaudella (Fingo 2019b).

Erilaisten konferenssien kautta pyrittiin edistämään komission strategioita vuosille 2020 2025. Virkakuntaa ja kansalaisjärjestöjä edustaneet haastateltavat näkivät tulevaisuuteen suuntautuvan työn tärkeänä, sillä aiempia komission tasa-arvon työpaperia ja seksuaalivähemmistöjä koskevaa toimintalinjausta pidettiin haastatteluissa sitoumukseltaan ja painoarvoltaan turhan keveinä. EU:n tasa-arvopolitiikan on nähty olleen pysähdyksissä tai jopa vastatuulessa talouskriisin ja oikeistopopulismin nousun jälkeen (Kantola 2016; Elomäki ja Kantola 2020). Perinteisten perhearvojen vahvistamisen mainittiin vaikuttaneen seksuaali- ja lisääntymisoikeuksien edistämiseen sekä naisiin kohdistuvan väkivallan ehkäisemiseen Euroopassa niin poliitikkojen kuin kansalaisjärjestöjen edustajienkin haastatteluissa. Toisaalta Suomen vahva painopistealue naisten ja tyttöjen oikeuksien edistämiseen kehityspolitiikassa tuotiin esiin. Suomi edisti osaltaan ratkaisun löytämistä kysymykseen EU:n liittymisestä naisiin kohdistuvan ja perheväkivallan vastaiseen Istanbulin sopimukseen. Joulukuun ministerineuvostossa hyväksyttiin tasa-arvoa koskevat päätelmät ja keskusteltiin tulevaisuuden tasa-arvopolitiikasta vastaavan komissaarin Helena Dallin kanssa.

Suomi on toiminut Euroopan neuvoston yhteydessä vahvasti sukupuoli- ja seksuaalivähemmistöjä koskevissa kysymyksissä ja yhteistyö EU-tasolla on edennyt muun muassa komission rahoittaman Rainbow Rights -kampanjan kautta (OM 2019). Yhteistyön komission asiantuntijoiden kanssa on nähty parantavan pienen jäsenmaan mahdollisuuksia edistää yksittäisiä aihekokonaisuuksia (Grøn ja Wivel 2011, 531). Suomi toimii EU:ssa yhdessä samanmielisten maiden kanssa ja on osallistunut vaatimuksiin edistää LHBTI-oikeuksia aiempaa tehokkaammin EU:ssa (TGEU 2018). Suomi järjesti syyskuussa komission ja EU:n perusoikeusviraston kanssa seksuaalivähemmistöjen oikeuksia käsittelevän konferenssin Brysselissä. Päätavoitteena oli luoda perusta komission LHBTI-strategialle ja komissio oli hankkeessa aloitteentekijänä. Konferenssi käsitteli sukupuoli- ja seksuaalivähemmistöjen oikeuksia jäsenmaissa sekä vihapuhetta ja järjestöjen toimintavapauksia. Koska seksuaalivähemmistöjä koskevat kysymykset ovat EU:ssa olleet kovassa vastatuulessa, virkakuntaan ja kansalaisjärjestöihin kuuluneet haastateltavat pitivät Suomen aktiivisuutta asiassa tarpeellisena. Poliittisella ja virkahenkilötasolla tehtiin työtä, jotta myös erimielisiä maita olisi saatu mukaan keskusteluun.

Suomessa pidettiin lisäksi European Disability Forumin (EDF) organisoima konferenssi koskien eurooppalaista esteettömyyslainsäädäntöä ja sen kansallista toimeenpanoa. Konferenssissa tarkasteltiin erityisesti rakennetun ympäristön ja liikenteen esteettömyyttä, joiden osalta Suomi näyttäytyy haastateltavien mukaan edelläkävijänä. Toisaalta kansalaisjärjestöjen 
edustajien haastatteluista ilmeni, että vammaiskysymysten näkyvyys oli Suomen kaudella pääosin kansalaisjärjestövetoista, eikä ohjelmassa alun perin ollut mitään vammaisaiheista tapahtumaa. Vammaisuuden näkyminen osana oikeusvaltioperiaatekeskustelua arvioitiin myös varsin vähäiseksi ja satunnaiseksi.

\section{Kestävä kehitys ja sosiaalinen oikeudenmukaisuus}

Kestävä kehitys ja YK:n Agenda 2030 -toimintaohjelman toimeenpano näkyi EU:n sisä- ja ulkopolitiikassa sekä yhdistettynä eri politiikka-aloille. Suomen ohjelmassa kestävyys oli sanana nostettu otsikkotasolle ja kestävän kehityksen eri ulottuvuuksia, kuten taloudellista, sosiaalista ja ekologista kestävyyttä huomioitiin laajalti. Lisäksi Suomen tavoitteena oli sisällyttää kestävään kehitykseen kulttuurinen ulottuvuus aiempaa vahvemmin. Suomi pyrki edistämään kestävää kehitystä ja sosiaalista oikeudenmukaisuutta painottamalla hyvinvointitaloutta, josta saavutettiin päätelmät lokakuussa. Sekä poliitikkojen että kansalaisjärjestöjen haastatteluissa hyvinvointitalous nostettiin yhdeksi Suomen kauden keskeiseksi onnistumiseksi ja sen sisältöjen koettiin edenneen osaksi komission ohjelmaa. Osana hyvinvointitaloutta painotettiin osallisuutta, yhdenvertaisia mahdollisuuksia kaikille sekä osaamisen merkitystä kestävässä talouskasvussa. Tähän liittyen Suomi järjesti ensimmäisen valtiovarainministerien ja opetusministerien yhteistapaamisen. Tärkeänä tapahtumana haastatteluissa mainittiin myös Helsingissä järjestetty Beyond Growth -konferenssi, joka käsitteli talouskasvun ja hyvinvoinnin yhteensovittamista sekä hyvinvoinnin mittareita.

Suomi laati puheenjohtajamaana selvityksen kestävän kehityksen pääviesteistä ja pitkän aikavälin strategiasta syyskuussa. Kansalaisjärjestöjen haastatteluissa Suomea kuvattiin kestävän kehityksen osalta edelläkävijänä ja esimerkkinä muille. Kestävän kehityksen osalta Suomen ja EU:n keskeisenä tavoitteena on ollut eriarvoisuuden vähentäminen (tavoite 10) sekä unionissa että globaalisti (VNK 2019, 11-12). EU:n sisällä eriarvoisuus on kasvanut ja EU:n ulkoisten toimien vaikutus eriarvoisuuden lisääntymiseen maailmassa ovat puhuttaneet. Neuvosto saavutti päätelmät eriarvoisuuden torjumisesta kumppanimaissa marraskuussa sekä päätelmät Agenda 2030 -toimintaohjelman toimeenpanosta joulukuussa. Toinen olennainen virkakuntaan ja kansalaisjärjestöihin kuuluvien haastateltavien esiin nostama teema oli tietoperustaisen päätöksenteon edistäminen ja luotettavan datan käyttö.

EU:n ilmastojohtajuuden vahvistaminen oli puheenjohtajuuskauden keskeinen prioriteetti. Joulukuun Eurooppa-neuvosto vahvisti EU:n ilmastoneutraaliustavoitteen vuoteen 2050 mennessä, tosin Puola oman aikataulunsa mukaisesti. Tavoite antoi komissiolle mandaatin valmistella lakiehdotuksen vuoden 2030 ilmastotavoitteen ja päästökaupan tiukentamisesta (haastattelu POL). Lisäksi ilmastoasiaa valtavirtaistettiin osaksi eri ministerineuvostojen agendaa (haastattelu VIR). Suomi vei eteenpäin keskustelua myös EU:n tavoitteiden päivittämisestä YK:ssa. Suomen puheenjohtajuuskauteen osui kansainvälisen ilmastosopimuksen osapuolikokous (COP25) joulukuussa, jossa EU piti yllä muita kunnianhimoisempaa linjaa. Ministeri Tuppurainen selvitti myös monivuotiseen rahoituskehykseen liittyvien ilmastorahoitustoimien perusteita. Suomen tavoitteena oli vähintään 25 prosentin sitominen ilmastotoimille komission ehdotuksen mukaisesti sekä kaiken EU-rahoituksen yhdenmukaisuus Pariisin ilmastosopimuksen tavoitteiden 
kanssa. Lisäksi maatalouden rahoituksen osalta merkittävä osuus (40 \%) tulisi Suomen ehdotuksessa ohjata ilmastotyöhön. Ilmastonmuutoksen torjunnassa Suomi edisti myös oikeudenmukaisesta siirtymästä käytyä keskustelua. Kansalaisjärjestöjen edustajat toivat lisäksi esiin maailman metsäkatoa ja metsien suojelua sekä biodiversiteettiä koskevat päätelmät joulukuulta.

Suomi edisti kiertotaloutta EU:ssa eri sektoreilla sekä pyrki viemään asiaa keskeiseen asemaan uuden komission ohjelmassa (EU2019.fi 2019a). Kiertotalouden kokonaisuudessa saavutettiin myös edistystä ja ympäristöneuvoston päätelmät esitettiin lokakuussa. Kiertotaloutta ja ilmastoteemaa edistettiin lisäksi erilaisin tempauksin Suomen edustustoissa ympäri maailmaa. Poliitikkojen haastatteluissa tuotiin esiin myös Suomen sitoumus kestäviin kokousjärjestelyihin; kokoukset keskitettiin Helsinkiin hyvien julkisen liikenneyhteyksien varrelle, puheenjohtajuuslahjojen sijaan kompensoitiin kokousvieraiden lentopäästöjä, kokouksissa suosittiin digitaalisia materiaaleja ja kestäviä valintoja ruoka- ja juomatarjoiluissa (EU2019.fi 2019b). Järjestelyillä pienennettiin hiilijalanjälkeä jopa 70 prosentilla tavanomaiseen kauteen verrattuna (EU2019.fi 2019c).

\section{SUOMEN PUHEENJOHTAJUUSKAUDEN ARVOPERUSTAISUUDEN ARVIOINTIA}

Yleisesti ottaen Suomen arvoperustaista ohjelmaa pidettiin useissa haastatteluissa varsin hyvänä. Kansalaisjärjestöt kiittelivät ohjelmaa kunnianhimon tasosta, useiden pehmeiden arvojen sisällyttämisestä sekä vaikeiden teemojen esille ottamisesta. Suomen painotusten koettiin saaneen myös myönteisen vastaanoton neuvoston eri kokoonpanoissa muilta jäsenmailta, komissiolta, parlamentilta sekä kansalaisjärjestöiltä. Neuvostossa Puola ja Unkari, jotka joutuivat oikeusvaltioperiaatetarkastelun alle, eivät tietenkään suhtautuneet Suomen lähestymistapaan myönteisesti (haastattelu POL; VIR). Toisaalta eräs haastateltu poliitikko tulkitsi Unkarin vahvan reaktion olleen nimenomaan osoitus Suomen onnistumisesta. Haastatteluissa oikeusvaltioperiaatteen ja sen vahvistamisen välineiden nähtiin olleen hyvin esillä eri yhteyksissä. Suomen esitys EU-varojen sitomisesta oikeusvaltioperiaatteen kunnioittamiseen eteni, mutta lopullista ratkaisua asiaan ei ole saatu ja useampi haastateltu ilmaisi huolensa tavoitteen etenemisestä. Sekä poliittisella että virkahenkilöpuolella pidettiin merkittävänä kuitenkin asian kirjaamista budjettiesitykseen.

Kansalaisjärjestöjen ja yksittäisten ihmisoikeuspuolustajien osallistaminen sai myös kiitosta useissa kansalaisjärjestöjen edustajien haastatteluissa. Suomen on arvioitu toimineen esimerkkinä muille jäsenmaille käytänteiden luomiseen ihmisoikeuspuolustajien kuulemiseksi (Amnesty 2020). Muutama haastatelluista poliitikoista myös mainitsi Suomen saaneen positiivista palautetta muilta jäsenmailta asianosaisten henkilöiden kutsumisesta kuultaviksi kokouksiin. Toisaalta eräs kansalaisjärjestön edustaja totesi haastattelussa vastaanoton olleen jäsenmaiden taholla varsin jakautunut. Yleisesti perusoikeuskysymyksiin liittyvien tavoitteiden koettiin edenneen useiden virkakuntaan ja kansalaisjärjestöihin kuuluvien haastateltavien mukaan jopa yli odotusten.

Sukupuolten tasa-arvon osalta arviointi on haastavaa, koska Suomen tavoitteena oli näkyä varsinaisten tasa-arvotapahtumien lisäksi muillakin politiikan aloilla tasa-arvokysymyksissä. Suomi onnistui edistämään tasa-arvoa erityisesti sosiaalisen ulottuvuuden kautta muun muassa työelämän käytännön kysymyksissä sekä kokonaisturvallisuuden teemassa. Valtavirtaistamisen 
osalta haastatellut poliitikot ja virkahenkilöt totesivat työn etenevän EU:ssa ylipäätään hitaasti. Suomen onnistumisia selitettiin institutionaalisen välivaiheen mahdollistamalla agendan asettamisella, uudenlaisten näkökulmien tarjoamisella ja tulevaisuuden linjausten ennakoinnilla. Useissa kaikkien toimijaryhmien haastatteluissa ajoituksen mainittiin sopineen erityisesti Suomen ajaman hyvinvointitalouden kokonaisuuden osalta, johon tasa-arvonäkökulmaa ja sukupuolivaikutusten arviointia integroitiin. Suomen onnistumista tukee se, että se sai European Women's Lobbylta (EWL) kirjeen, jossa kiitettiin johtajuutta naisten oikeuksien edistämisessä ja valtavirtaistamisessa. Suomen kaudella tehtyjen tasa-arvopäätelmien ja teemojen vaikutukset näkyvät myös komission uudessa tasa-arvostrategiassa (EU Komissio 2020). Toisaalta useat haastateltavista kaikista ryhmistä nostivat esiin sukupuolten tasa-arvon näkyvyyteen vaikuttaneet muut seikat, kuten Sanna Marinin nousun pääministeriksi, Ursula von der Leyenin valinnan komission johtoon sekä Helena Dallin valinnan tasa-arvosta vastaavaksi komissaariksi. Von der Leyen on sitoutunut ohjelmassaan erityisesti tasa-arvon edistämiseen (Elomäki ja Kantola 2020, 47). Näin ollen Suomen toimia on tarkasteltavana osana laajempaa kontekstia.

Tasa-arvon osalta kauden huomio oli kuitenkin pitkälti nimenomaan sukupuolten tasa-arvossa. Virkakunnan ja kansalaisjärjestöjen edustajien haastatteluissa tuotiin esiin, kuinka Suomi olisi voinut toimia näkyvämmin laajemman yhdenvertaisuuden edistämiseksi. Esimerkiksi vammaiskysymyksissä ja seksuaalisia vähemmistöjä koskevissa kysymyksissä aiemman hallituksen vaisu linja tuntui vaikuttaneen kysymysten esilläoloon ja tapahtumien suunnitteluun. Näissä kysymyksissä eteneminen jäi haastateltavien mukaan järjestöjen, muiden jäsenmaiden, komission tai yksittäisten henkilöiden varaan. Hallituskokoonpanolla onkin nähty olevan keskeinen rooli seksuaali- ja sukupuolivähemmistöihin liittyvää politiikkaa koskien. Toisaalta konservatiivinen politiikka on myös vaikuttanut kansalaisjärjestöpuolen aktivoitumiseen. (Järviö 2020, 119.) Haastatteluissa korostettiin Suomen vaikeaa tasapainottelua edistyksellisyyden ja perinteisyyden välillä sekä omassa linjassaan että Euroopassa tasa-arvokysymysten politisoitumisesta johtuen (ks. Elomäki ja Kantola 2020, 34). Suomelle onkin ollut usein helpompaa painottaa tasa-arvo- ja yhdenvertaisuuskysymyksissä ulkopoliittista ulottuvuutta ja kansainvälistä yhteistyötä (Jauhola ja Lyytikäinen 2020, 163-164).

Suomen perinteisesti omaksuma neutraali ja asiapitoinen linja jakoi haastateltavien mielipiteitä. Toisaalta linjan mainittiin toimineen sellaisia jäsenmaita kohtaan hyvin, jotka ovat usein haluttomia ottamaan kantaa perusoikeuskysymyksissä tai oikeusvaltioteemassa. Suomen neutraalius herätti sen sijaan kritiikkiä ilmasto- ja ympäristötoimissa sekä kehityspolitiikassa. Haastatellut kansalaisjärjestöjen edustajat nostivat esiin kysymyksen siitä, pakeniko Suomi osin roolinsa taakse ja jäi sen varjolla kunnianhimoisista tavoitteista. Erityisesti ilmastopuolella toimet koettiin ristiriitaisina, sillä neutraaliin linjaansa vedoten Suomi ei esittänyt vahvoja kantoja puolueiden ilmastolinjauksen mukaisesti. Suomi tuntuikin ilmastopolitiikassa toteuttavan melko keskikastista roolia, jota sille on tutkimuksessa ehdotettu (Carter ym. 2019, 991).

Jotkut haastatellut kansalaisjärjestöjen edustajat nostivat myös esiin, että Suomen johtajuutta murensivat sen neuvottelemat erivapaudet metsäkadon ja maatalousmaiden päästöjen laskennassa (ks. myös SLL 2020). Tässä Suomi toisti rooliaan itseään koskevien poikkeusten hakijana (ks. Laurila ja Niemi 2017, 164). Myöskään korkean tason ilmastohuippukokousta ei järjestetty joulukuussa, kuten oli suunniteltu. Epävirallisempien huippukokousten avulla puheenjohtajan 
on mahdollista profiloitua ja edistää virallisia neuvotteluja (Alexandrova ja Timmermans 2013, 320; Ojanen 2018, 19-20). Haastateltujen poliitikkojen ja kansalaisjärjestötoimijoiden mukaan huippukokous olisikin todennäköisesti vahvistanut Suomen profiloitumista ilmastokysymyksessä. Onnistumisena nostettiin esiin hiilineutraaliustavoitteet ja niiden yhteys komission vihreän ohjelman ripeään julkaisemiseen.

Suomella on perinteisesti ollut puheenjohtajuuskausillaan vahva fokus EU:n ulkoisessa toiminnassa (Ojanen 2018, 12). Lissabonin sopimuksen jälkeen puheenjohtajan muuttunut rooli ohjaa sen tukemaan korkean edustajan työtä. Haastatellut virkakunnan ja kansalaisjärjestöjen edustajat toivat esiin useiden ulkosuhdekysymysten haastavuuden ja isojen maiden intressit, joista johtuen eteneminen oli monesti vaikeaa. Kestävän kehityksen osalta neuvoston työryhmässä edettiin haastateltavien mukaan hyvin, vaikka tämä ei välttämättä näkynyt otsikoissa. Sosiaalisen oikeudenmukaisuuden ja ekologisen kestävyyden teemojen nähtiin vahvistuneen kokonaisuutena puheenjohtajuuskauden aikana (Fingo 2020). Haastatellut kansalaisjärjestöjen edustajat kokivat Suomen painotusten myös edenneen komission strategioiden sisältöihin. Suomen ohjelmaa arvosteltiin kuitenkin siitä, että kestävä kehitys ja talouskasvu muodostivat siinä ristiriitaisen parin. Puhumalla kestävästä kasvusta sekoitettiin käsitteitä. (Fingo 2019a.) Haastatteluissa sisäisen kestävyyden näkökulman todettiin myös painottuneen ulkoisen kustannuksella, eikä Suomen nähty käyttäneen tilaisuutta hyväkseen kehitys- ja kauppapolitiikassa toivotulla tavalla. Ulkosuhteiden rahoituksen osalta päätökset jäivät saavuttamatta, mikä oli järjestöille pettymys. Suomi sai kuitenkin kiitosta niiden kokousten osalta, joissa se edusti EU:ta.

Maahanmuutto- ja turvapaikkapolitiikan osalta Suomen toimet olivat useiden haastateltujen poliitikkojen ja kansalaisjärjestöjen edustajien mielestä pettymys (ks. myös Amnesty 2020). Maahanmuuttoteema jäi ohjelmassa toissijaiseksi, vaikka valmistelussa se oli ollut keskeinen. Toisaalta virkakunnan ja kansalaisjärjestötoimijoiden haastatteluissa mainittiin useamman puheenjohtajamaan ohittaneen aiheen vastoin komission toiveita. Pakolaiskriisin jälkeen EU:n maahanmuutto- ja turvapaikkapolitiikka on ajautunut kriisiin ja jäsenmaat odottivat uuden komission ehdotusta politiikan uudistamisesta. Toisaalta virkahenkilöiden ja poliitikkojen haastatteluissa todettiin myös, ettei Suomelta näistä vaikeuksista johtuen juuri odotettukaan mitään suuria saavutuksia. Näin ollen kauden ohjelmassakin puhuttiin vain mahdollisesta etenemisestä yksittäiskysymyksissä (VNK 2019). Suomen kaudella hyväksi miellettiin kuitenkin yhteisen politiikan ongelmakohdista käyty perusteellinen keskustelu, joka pohjusti komission lopulta syyskuussa 2020 julkaistua uudistusehdotusta. Kansalaisjärjestöjen edustajat nostivat esiin myös hallitusohjelmatasollakin näkyneet korjausliikkeet suhteessa Sipilän hallituksen maahanmuuttolinjauksiin. Suomi jäi silti syyskuussa käyttöönotetun Välimereltä pelastettujen siirtolaisten väliaikaisen mekanismin ulkopuolelle, vaikka ilmoitti tukevansa neuvotteluja. Kuten artikkelin alussa todettiin, maahanmuuttokysymykset ovat Suomen EU-politiikassa eräs jakavimpia kysymyksiä. Perinteisemmin Suomi on korostanut EU:n yhteisen rajavalvonnan ja sen toimintakyvyn kehittämistä sekä tietojärjestelmien yhteensovittamista (Tuominen 2020). Suomen huomio keskittyi puheenjohtajuuskaudella enemmän rajaturvallisuuteen ja palautuskysymyksiin, painotus, joka haastateltujen kansalaisjärjestöjen edustajien mukaan kyseenalaisti halun toimia ihmisoikeusperustaisesti. 


\section{KESKUSTELUA}

Artikkelin aineiston valossa arvojen voidaan todeta nousseen Suomen puheenjohtajakauden keskiöön useiden tekijöiden myötävaikutuksesta. Ensinnäkin arvokysymykset olivat olleet vahvasti esillä EU-tasolla ja niiden merkitys kasvoi kauden lähestyessä. Suomelle oli näin ollen luonnollista valita keskustelussa olleet oikeusvaltioperiaate ja ilmastoasiat puheenjohtajakautensa prioriteeteiksi. Tämän näkökulman mukaan Eurooppa-neuvoston yleinen asialista muokkaa vahvasti Suomen EU-politiikkaa, jota on luonnehdittu varsin reaktiiviseksi (vrt. Hyvärinen ja Raunio 2014, 98; Raunio ja Saari 2017, 224). Toisekseen, kansallisessa valmistelussa saavutettiin konsensus arvojen tärkeydestä jo varhain ja uuden hallituksen kokoonpano vahvisti ohjelman arvopainotteisuutta. Haastatteluissa mainittiin Rinteen (ja Marinin) ilmiöpohjaisen hallitusohjelman vahva arvopainotus ja sen merkittävä ero suhteessa edeltäjäänsä. Sipilän strategisempi ohjelma onkin saanut kritiikkiä erityisesti tasa-arvoon liittyvissä kysymyksissä (Kantola ym. 2020, 20). Vaikka EU-politiikan jännitteet ovat kasvaneet Suomessa 2010-luvulla (Raunio 2016; Raunio ja Mattila 2017), puheenjohtajuuskauden valmistelun kuvattiin tapahtuneen puoluepoliittisesti ja koordinaation osalta varsin yhtenäisessä hengessä. Lisäksi virkakunnan ylläpitämä EU-politiikan jatkuvuus ja poliittisen ohjelman arvopainotus onnistuttiin sovittamaan yhteen ilman suurempia ongelmia. Kansalaisjärjestöt kiittelivät ohjelman arvopainotteisuutta, mutta heidän osuutensa sen valmistelussa oli lopulta varsin rajattua.

Kuten artikkeli osoittaa, Suomen toimet arvokysymyksissä eivät jääneet pelkän julkisuudessa näkyneen oikeusvaltioperiaatteen puolustamiseen, vaan kaudella edistettiin muitakin perusarvoja. Suomen pragmaattinen lähestymistapa arvoihin muokkasi politiikan tekoa ja tehosti politiikkasektoreiden yhteistyötä muun muassa talous- ja sosiaalipolitiikan, kokonaisturvallisuuden, perusoikeuksien ja ilmastokysymysten hallinnassa. Ministeriöiden välisen toimivan yhteistyön onkin todettu myötävaikuttavan pienten jäsenmaiden puheenjohtajuuksien onnistumiseen (Elgström 2003; Bunse 2009). Suomi tarjosi kansallisesti omaksuttuja käytänteitään, kuten hyvinvointitaloutta ja sukupuolitietoista budjetointia, osaksi laajempaa EU:n päätöksentekoa. Suomi on aiemmin vastaavalla tavalla ajanut EU:ssa muun muassa pohjoista ulottuvuutta (Arter 2000; Ojanen ja Raik 2017). Suomi toimi monien abstraktien arvojen kohdalla innovatiivisesti, yhdistäen politisoitunutta arvokeskustelua käytännön toimeenpanoon ja arvojen toteutettavuuteen. Näin ollen keskustelua arvoista ei jätetty pelkän puheen tasolle, vaan niistä väännettiin konkreettisten toimenpiteiden kautta. Grøn ja Wivel $(2011,534)$ korostavat innovatiivisten avausten merkitystä pienten jäsenmaiden keinona normien edistämisessä.

Oliko arvoperustaisuuden valinta lopulta onnistunut Suomen kaudella ja edettiinkö asioissa toivotulla tavalla? Kuten artikkelin alussa tuotiin esiin, puheenjohtajuuden onnistumista on vaikeaa arvioida, sillä mitään yksiselitteistä mittaristoa ei ole ja kausaalisuhteiden osoittaminen on haasteellista (ks. Vandecasteele ja Bossyut 2014). Lisäksi on usein vaikeaa määritellä, kenen ansiosta asiat lopulta etenevät. Kaudelle asetettujen tavoitteiden valossa työ meni eteenpäin ja tässä mielessä Suomi onnistui monilta osin. Arvoperustaisessa ohjelmassa yhdistyivät kansalliset ja eurooppalaiset intressit. Suomen menestys oli vahvasti sidoksissa sen perinteiseen neutraaliin ja asiapitoiseen toimintatapaan (Raunio ja Saari 2017, 223), vaikka osin liiallista neutraaliutta myös arvosteltiin. Merkittävintä kauden antia olivat tulevaisuuteen suuntautuvat keskustelut ja päätelmät, joita institutionaalinen välivaihe mahdollisti ja joiden hedelmät ovat 
osin nähtävissä uuden komission työssä. Samanaikaisesti kansalaisjärjestöpuolen näkemyksissä oli kiitosten ohella moitteita asiakokonaisuuksista, joissa työ jäi kesken ja jossa vaikuttamista ei juuri tapahtunut. Useampi haastateltu mainitsi Suomen nostaneen esiin vaikeita arvokysymyksiä, joita aiemmat puheenjohtajamaat olivat vältelleet. Tässä mielessä Suomi pärjäsi ainakin jäsenmaiden välisessä vertailussa, joskin odotukset pienen jäsenmaan osalta voivat olla vähäisemmät. Hyvä kysymys onkin, mitä Suomen puheenjohtajuuskaudelta oli realistisesti arvioituna odotettavissa. Joissain asiakokonaisuuksissa, kuten maahanmuutossa, etenemismahdollisuuksia ei juurikaan ollut. Tutkimuksen jatkotyöstäminen niin, että aineisto sisältäisi myös ulkopuolisten (eli ei-suomalaisten) näkemyksiä kauden onnistumisesta, tarjoaisi tärkeitä täydentäviä tulokulmia kauden arviointiin.

Voidaan myös laajemmin pohtia, mitä arvoperustaisuuden nosto puheenjohtajuuskauteen tarkoittaa Suomen EU-politiikan linjan ja viiteryhmien osalta. Arvopainotusta voidaan lähestyä perinteisen pragmaattisuuden ja reaktiivisuuden ilmentymänä (Tiilikainen 2003a; Ojanen ja Raunio 2018). Kuten alussa todettiin, arvot ovat olleet Suomen EU-politiikassa käytännön sijaan periaatteiden tasolla. Sittemmin Suomen arvolinjausten on tulkittu olevan mahdollisesti jopa aiempaa epävarmempia (Ojanen ja Raik 2017, 194). Lisäksi jäsenmaiden jakautuminen on ongelmallista sekä neuvoston työn että Suomen neutraaliuden vaalimisen näkökulmasta (Ojanen 2018, 14). Arvoperustaisuuden valintaa voitaisiin siis pitää yllättävänä ja riskialttiinakin valintana. Toisaalta taas kolmas puheenjohtajuus oli Suomelle ehkä eräänlainen "täysi-ikäisyyden" paikka ja edellytti aiempaa rohkeampaa linjaa. Tälle uusi EU-myönteinen hallitus antoi lopulta mahdollisuuden.

Artikkelin aineiston pohjalta jää edelleen avoimeksi, miten pitkälle Suomen edistämät asiat kantavat ja saadaanko niiden ansiosta aikaan muutoksia EU-päätöksenteossa. Ensiarvoisen tärkeää arvoperustaisuuden kannalta on tulevaisuudessa se, että vaikeuksista huolimatta myös muut jäsenmaat kantavat kortensa kekoon arvokysymyksissä. Lisäksi EU-instituutioiden on jatkettava pitkäjänteisesti työtä yhteisten arvojen puolustamiseksi, ennen kaikkea hangoittelevia jäsenmaita vastaan. Tätä EU:n arvoperustaisuuden vaaliminen viime kädessä merkitsee.

\section{VIITTEET}

1. Haluan kiittää Hanna Ojasta, Henri Vogtia, Politiikka-lehden päätoimitusta sekä kahta vertaisarvioijaa hyvistä kommenteista käsikirjoituksen aiempiin versioihin. Lisäksi haluan kiittää kaikkia haastatteluihin osallistuneita, joiden näkemykset moninaistivat kuvaa Suomen EU-puheenjohtajakauden arvopainotuksesta.

2. Lissabonin sopimuksen mukaisesti Eurooppa-neuvosto sai pysyvän puheenjohtajan ja EU:n ulkosuhteiden korkea edustaja vastaa ulkoasioiden johdosta ulkosuhdehallinnon kanssa. Euroryhmä työskentelee omana kokonaisuutenaan.

3. Eurooppalaisista kattojärjestöistä muun muassa Amnesty International, European Women’s Lobby (EWL), European Disability Forum (EDF) ja European Confederation of Relief and Development (Concord) julkaisivat omat, Suomen puheenjohtajuutta koskevat toiveensa.

4. Osa haastatteluista toteutettiin kuitenkin kasvokkain. Suurin osa haastatteluista myös tallennettiin. Tallenteet, haastattelujen muistiinpanot sekä litteroinnit ovat kirjoittajan hallussa. Artikkelin 
valmista käsikirjoitusta kommentoi 15 haastateltavaa. Kiitän haastateltavia erinomaisista tarkentavista huomioista.

\section{LÄHTEET}

Alastalo, Marja ja Åkerman Maria. 2010. Asiantuntijahaastattelun analyysi: faktojen jäljillä. Teoksessa Johanna Ruusuvuori, Pirjo Nikander ja Matti Hyvärinen (toim.), Haastattelun analyysi. Tampere: Vastapaino, 372-392

Alastalo, Marja, Åkerman, Maria ja Vaittinen Tiina. 2017. Asiantuntijahaastattelu. Teoksessa Matti Hyvärinen, Pirjo Nikander ja Johanna Ruusuvuori (toim.), Tutkimushaastattelun käsikirja. Tampere: Vastapaino, 211-230.

Alexandrova, Petya ja Timmermans Arco. 2013. National interest versus the common good: The Presidency in European Council agenda setting. European Journal of Political Research 52:3, 316-338. https://doi.org/10.1111/j.1475-6765.2012.02074.x.

Amnesty. 2018. Ihmisoikeuspuolustajien tukeminen Suomen EU-puheenjohtajakauden prioriteetiksi, lausunto suurelle valiokunnalle, 16.10.2018. https://www.eduskunta.fi/FI/naineduskuntatoimii/julkaisut/ aineistot/Documents/Amnesty\%20International\%20Suomen\%20osasto.pdf. Viitattu 16.11. 2020.

Amnesty. 2020. Miten meni, Suomi? Amnesty ruotii EU-puheenjohtajakauden kohokohdat ja pettymykset. https://www.amnesty.fi/miten-meni-suomi-amnesty-ruotii-eu-puheenjohtajakauden-kohokohdat-ja-pettymykset/. Viitattu 25.5.2020.

Arter, David. 2000. Small state influence within the EU: the case of Finland's "northern dimension initiative". Journal of Common Market Studies 38:5, 677-697. https://doi.org/10.1111/1468-5965.00260.

Björkdahl, Annika. 2008. Norm advocacy: a small state strategy to influence the EU. European Public Policy 15:1, 135-154. https://doi.org/10.1080/13501760701702272.

Bunse, Simone. 2009. Small states and EU Governance: leadership through the Council Presidency. Lontoo: Palgrave Macmillan.

Carter, Neill, Little, Conor ja Torney Diarmuid. 2019. Climate politics in small European states. Environmental Politics 28:6, 981-996. https://doi.org/10.1080/09644016.2019.1625144.

Checkel, Jeffrey ja Katzenstein Peter. 2009. The Politicization of European Identities. Teoksessa Jeffrey Checkel ja Peter Katzenstein (toim.), European Identity. Cambridge: Cambridge University Press, $1-25$.

Closa, Carlos. 2016. Reinforcing EU Monitoring of the Rule of Law. Normative Arguments, Institutional Proposals and the Procedural Limitations. Teoksessa Carlos Closa ja Dimitry Kochenov (toim.), Reinforcing the Rule of Law Oversight in the European Union. Cambridge: Cambridge University Press, 15-35. https://doi-org.libproxy.helsinki.fi/10.1017/CBO9781316258774

Closa, Carlos ja Kochenov Dimitry. 2016. Introduction. Teoksessa Carlos Closa ja Dimitry Kochenov (toim.), Reinforcing the Rule of Law Oversight in the European Union. Cambridge: Cambridge University Press, $1-12$.

Dunne, Tim. 2018. Ethical Foreign Policy in a Multipolar World. Teoksessa Chris Brown ja Robyn Eckersley (toim.), The Oxford Handbook of International Political Theory. Oxford: Oxford University Press, 495-507. 
Eduskunta. 2018a. Eduskuntaryhmien näkemyksiä: Suomen EU-puheenjohtajuuden ohjelma 17.10.2018. https://www.eduskunta.fi/FI/naineduskuntatoimii/julkaisut/aineistot/Documents/Eduskuntaryhmat_Suomen_EUpuheenjohtajakausi.pdf. Viitattu 20.5.2020.

Eduskunta. 2018b. Täysistunnon pöytäkirja PTK 129/2018 vp, saatavilla https://www.eduskunta.fi/FI/ vaski/PoytakirjaAsiakohta/Sivut/PTK_129+2018+8.aspx. Viitattu 24.4.2020.

Elgström, Ole (toim.). 2003. European Union Council Presidencies. A Comparative Perspective. Lontoo ja New York: Routledge.

Elomäki, Anna ja Kantola Johanna. 2020. Tasa-arvopolitiikan suunnanmuutos Euroopan unionissa. Teoksessa Johanna Kantola, Paula Koskinen Sandberg ja Hanna Ylöstalo (toim.), Tasa-arvopolitiikan suunnanmuutoksia. Talouskriiseistä tasa-arvon kriiseihin. Helsinki: Gaudeamus, 33-47.

EU komissio. 2014. Komission tiedonanto Euroopan parlamentille ja neuvostolle, COM 2014/158, 11.3.2014. Uusi EU:n toimintakehys oikeusvaltioperiaatteen vahvistamiseksi. https://eur-lex.europa.eu/ legal-content/FI/TXT/HTML/?uri=CELEX:52014DC0158\&from=EN. Viitattu 18.5.2020.

EU komissio. 2018. Komission ehdotus unionin talousarvion suojaamisesta tilanteissa, joissa oikeusvaltioperiaatteen noudattamiseen jäsenvaltioissa kohdistuu yleisiä puutteita, COM 2018/324, 2.5.2018. https://eur-lex.europa.eu/legal-content/FI/TXT/PDF/?uri=CELEX:52018PC0324\&from=FI. Viitattu 22.5. 2020.

EU komissio. 2019. Komission tiedonanto Euroopan parlamentille ja neuvostolle, COM 2019/343 final. Oikeusvaltioperiaatteen lujittaminen unionissa. Toimintasuunnitelma, 17.7.2019. https://eur-lex.europa.eu/legal-content/FI/TXT/PDF/?uri=CELEX:52019DC0343\&from=EN. Viitattu 27.5.2020.

EU komissio. 2020. Gender Equality Strategy 2020-2025. https://ec.europa.eu/info/policies/justice-andfundamental-rights/gender-equality/gender-equality-strategy_en. Viitattu 29.5. 2020.

EU neuvosto. 2014. Rule oflaw dialogue, 16.12.2014. https://www.consilium.europa.eu/media/24875/146323. pdf. Viitattu 19.11.2020.

EU neuvosto. 2015. Declaration on Promoting citizenship and the common values of freedom, tolerance and non-discrimination through education, 17.3. 2015. http://ec.europa.eu/assets/eac/education/ news/2015/documents/citizenship-education-declaration_en.pdf. Viitattu 17.5.2020.

EU neuvosto. 2018. Neuvoston 18 kuukauden ohjelma, 30.11.2018. http://data.consilium.europa.eu/doc/ document/ST-14518-2018-INIT/fi/pdf. Viitattu 14.5.2019.

EU neuvosto. 2019. Neuvoston päätelmät demokratiasta, 14.10. 2019. https://data.consilium.europa.eu/ doc/document/ST-12836-2019-INIT/fi/pdf. Viitattu 27.5. 2020.

Eurooppa-neuvosto. 2017. Rooman julistus, 25.3. 2017. https://www.consilium.europa.eu/en/press/ press-releases/2017/03/25/rome-declaration/. Viitattu 30.5.2020.

Eurooppa-neuvosto. 2019. Uusi strateginen ohjelma 2019-2024, 20.6.2019. https://www.consilium.europa.eu/media/39915/a-new-strategic-agenda-2019-2024-fi.pdf.Viitattu 19.5. 2020.

EU2019.fi. 2019a. Puheenjohtajuuskauden taustoitus: Kiertotalous 2.0, https://eu2019.fi/taustoitukset/ kiertotalous. Viitattu 28.5. 2020.

EU2019.fi. 2019b. Kestävyyden huomioinnista puheenjohtajuusjärjestelyissä, ks. https://eu2019.fi/eupuheenjohtajuus/kestavat-kokousjarjestelyt. Viitattu 24.4. 2020.

EU2019.fi. 2019c. Puheenjohtajakauden yhteenveto: https://eu2019.fi/eu-puheenjohtajuus/yhteenveto. Viitattu 29.5. 2020.

Feliu, Laura ja Serra Francesc. 2015. The European Union as a 'Normative Power' and the Normative Voice of the European Parliament. Teoksessa Stelios Stavridis ja Daniela Irrera (toim), The European 
Parliament and Its International Relations. Lontoo ja New York: Routledge, 17-34.

Fingo. 2020. EU-puheenjohtajuuskauden hitit ja hudit, 10.2.2020. https://www.fingo.fi/ajankohtaista/analyysit/suomen-eu-puheenjohtajuuskauden-hitit-ja-hudit. Viitattu 27.5. 2020.

Fingo. 2019a. Suomen EU-puheenjohtajuuskausi järjestöissä podcast, 2.7.2019. https://www.fingo.fi/ajankohtaista/blogit/kuuntele-suomen-eu-puheenjohtajuuskausi-jarjestoissa. Viitattu 20.5. 2020.

Fingo. 2019b. Tasa-arvoisen EU:n tekijät kampanjasivut ja ministereiden vastaukset, ks. https://www. fingo.fi/eu-puheenjohtajuus/tasa-arvokampanja. Viitattu 24.4.2020.

Foret, François ja Calligaro Oriane 2018. Analysing European Values. An Introduction. Teoksessa François Foret ja Oriane Calligaro (toim.), European Values. Challenges and Opportunities for EU Governance. Lontoo ja New York: Routledge, 1-20.

Furedi, Frank. 2018. Populism and the European Culture Wars. The Conflict of Values between Hungary and the EU. Lontoo and New York: Routledge.

Grøn, Caroline H. ja Wivel Anders. 2011. Maximizing Influence in the European Union after the Lisbon Treaty: From Small State Policy to Smart State Strategy. Journal of European Integration 33:5, 523-539. https://doi.org/10.1080/07036337.2010.546846

Hyvärinen, Anna ja Raunio Tapio. 2014. Mistä EU-asioista hallitus keskustelee ja kenen aloitteesta? Suomen hallituksen Eurooppa-politiikan koordinaatio vuosina 1995-2012. Politiikka 56:2, 87-100.

Häge, Frank. 2017. The scheduling power of the EU Council Presidency. Journal of European Public Policy 24:5, 695-713. https://doi.org/10.1080/13501763.2016.1158203.

Jauhola, Marjaana ja Lyytikäinen Minna. 2020. Kutistettu feminismi? Suomen ulkosuhteiden tasa-arvopolitiikka kylmän sodan YK-feminismistä 2010-luvun tolkkutasa-arvoon. Teoksessa Johanna Kantola, Paula Koskinen Sandberg ja Hanna Ylöstalo (toim.), Tasa-arvopolitiikan suunnanmuutoksia. Talouskriiseistä tasa-arvon kriiseihin. Helsinki: Gaudeamus, 150-166.

Järviö, Nina. 2020. Translaki ja transpolitiikan nousu. Teoksessa Johanna Kantola, Paula Koskinen Sandberg ja Hanna Ylöstalo (toim.), Tasa-arvopolitiikan suunnanmuutoksia. Talouskriiseistä tasa-arvon kriiseihin. Helsinki: Gaudeamus, 113-128.

Kantola, Johanna. 2016. Euroopan unioni sukupuolten tasa-arvoa edistämässä. Teoksessa Kajanoja, Jouko ja Yrjö-Koskinen, Eero (toim.), Hajoaako Unioni - kirjoituksia EU:n kohtalonkysymyksistä. Helsinki: Into kustannus, 81-98.

Laurila, Ilkka ja Niemi Jyrki. 2017. Kansallista konsensusta: Suomen maatalouden selviytyminen EUaikana. Teoksessa Tapio Raunio ja Juho Saari (toim.), Reunalla vai ytimessä? Suomen EU-politiikan muutos ja jatkuvuus. Helsinki: Gaudeamus, 149-169.

Lewis, Jeffrey. 2013. The Council of the European Union and the European Council. Teoksessa Michelle Cini ja Nieves Pérez-Solórzano Borragán (toim.), European Union Politics. Neljäs painos. Oxford: Oxford University Press 142-149.

Lucarelli, Sonia ja Manners Ian (toim.). 2006. Values and Principles in EU Foreign Policy. Lontoo: Routledge. Magen, Amichai. 2016. Cracks in the Foundations: Understanding the Great Rule of Law Debate in the EU. Journal of Common Market Studies 54:5, 1050-1061. https://doi.org/10.1111/jcms. 12400

Manners, Ian. 2002. Normative Power Europe: A Contradiction in Terms? Journal of Common Market Studies 40:2, 235-258. https://doi.org/10.1111/1468-5965.00353

Manners, Ian. 2006. The constitutive nature of values, images and principles in the European Union. Teoksessa Sonia Lucarelli ja Ian Manners (toim.), Values and Principles in EU Foreign Policy. Lontoo: Routledge, 19-41. 
Marin, Sanna. 2019. Letter to the President of the European Council, 11.12. 2019. https://eu2019.fi/documents/11707387/13552730/FI+PM+Marin+letter+to+PEC+Michel+on+the+implementation + of $+\mathrm{t}$ he+Strategic+Agenda.pdf/aad0f386-6e83-8790-27a3-5af5fb5ebb17/FI+PM+Marin+letter+to+PEC+ Michel+on+the+implementation+of+the+Strategic+Agenda.pdf. Viitattu 22.5. 2020.

Martikainen, Tuomo ja Tiilikainen Teija. 2000 (toim.). Suomi EU:n johdossa. Tutkimus Suomen puheenjohtajuudesta 1999. Helsinki: Helsingin yliopisto.

Müller, Jan-Werner. 2016. Protecting the rule of law (and democracy!) in the EU. The idea of a Copenhagen Commission. Teoksessa Carlos Closa ja Dimitri Kochenov (toim.), Reinforcing the Rule of Law Oversight in the European Union. Cambridge: Cambridge University Press, 206-224.

Ojanen, Hanna. 2018. Suomen EU-puheenjohtajuus: mitä kolmas kerta sanoo? Kalevi Sorsa säätiö. https:// sorsafoundation.fi/suomen-eu-puheenjohtajuus-mita-kolmas-kerta-sanoo/. Viitattu 17.5. 2020.

Ojanen, Hanna ja Raik Kristi. 2017. Ulko- ja turvallisuuspolitiikka: pinnallista jatkuvuutta ja pyörteisiä pohjavirtauksia. Teoksessa Tapio Raunio ja Juho Saari (toim.), Reunalla vai ytimessä? Suomen EUpolitiikan muutos ja jatkuvuus. Helsinki: Gaudeamus, 170-195.

Ojanen, Hanna ja Raunio Tapio. 2018. Re-Assessing Finland's Integration Policy: The End of Domestic Consensus? Teoksessa Malin S. McCallion ja Alex Brianson (toim.), Nordic States and European Integration: Awkward Partners in the North? Cham: Palgrave Macmillan, 35-58.

Ojanen, Hanna ja Vuohula Eero. 2007. The Finnish Presidency: Efficiency Before Eloquence? Journal of Common Market Studies 45:1, 17-24. https://doi.org/10.1111/j.1468-5965.2007.00732.x.

OM. 2019. Rainbow rights -hankesivut: https://oikeusministerio.fi/rainbow-rights. Viitattu 25.4.2020.

Raik, Ele. 2015. The 'trio presidency' of the Council of the European Union: Towards More continuity? Baltic Journal of European Studies 5:1, 19-35. https://doi.org/10.1515/bjes-2015-0003.

Raivio, Petri ja Stenroos Maria. 2019. Suomi jäi pois tiukkoja päästövähennyksiä vaativien maiden ryhmästä - Sipilä: Syynä lähestyvä EU-puheenjohtajuus, julkaistu 9.9. 2019. https://yle.fi/uutiset/3-10776226. Viitattu 4.6. 2020.

Raunio, Tapio. 2016. The politicization of EU affairs in the Finnish Eduskunta: Conflicting logics of appropriateness, party strategy or sheer frustration? Comparative European Politics 14:2, 232-252. http://dx.doi.org/10.1057/cep.2015.41.

Raunio, Tapio ja Mattila Mikko. 2017. Kun yksituumaisuus murenee: EU-politiikan kansallinen valmistelu ja päätöksenteko. Teoksessa Tapio Raunio ja Juho Saari (toim.), Reunalla vai ytimessä? Suomen EU-politiikan muutos ja jatkuvuus. Helsinki: Gaudeamus, 52-70.

Raunio, Tapio ja Saari Juho. 2017. Onko konsensuksen aika ohi? Teoksessa Tapio Raunio ja Juho Saari (toim.), Reunalla vai ytimessä? Suomen EU-politiikan muutos ja jatkuvuus. Helsinki: Gaudeamus, 9-25.

Raunio, Tapio ja Tiilikainen Teija. 2003. Finland in the European Union. London: Taylor \& Francis.

Risse, Thomas. 2010. A Community of Europeans? Transnational Identities and Public Spheres. Ithaca: Cornell University Press.

Schout, Adrian. 2017. The Dutch EU Presidency: The Continuing Relevance of the Rotating Presidency in the Political Union. Journal of Common Market Studies 55:S1, 54-63. https://doi.org/10.1111/ jcms.12576.

Sipilä, Juha 2019. Kasvu, turvallisuus, ilmasto, arktinen politiikka - Kohti vaikuttavaa EU-puheenjohtajuuskautta, julkaistu 5.4.2019. https://www.juhasi.fi/blogi/kasvu-turvallisuus-ilmasto-arktinen-politiikka-kohti-vaikuttavaa-eu-puheenjohtajuuskautta/. Viitattu 8.5.2020. 
SLL. 2020. Suomen EU-puheenjohtajuuskauden suurin ilmastovoitto oli voitto maailman metsille. https:// www.sll.fi/2020/01/22/suomen-eu-puheenjohtajuuskauden-suurin-ilmastovoitto-oli-voitto-maailman-metsille/. Viitattu 28.5. 2020.

STM. 2019. Trio Presidency Declaration on Gender Equality, 15.3.2019. https://stm.fi/documents/1271139/14654750/Trio+Presidency+Declaration+on+Gender+Equality.pdf/a30044d1-38286665-3d86-589e59b370e5/Trio+Presidency+Declaration+on+Gender+Equality.pdf. Viitattu 28.5. 2020.

Stubb, Alexander. 2000. The Finnish Presidency. Journal of Common Market Studies 38:S1, 49-53. https:// doi.org/10.1111/1468-5965.38.s1.5.

TGEU. 2018. Joint non-paper on the future of the LGBTI list of actions, https://tgeu.org/wp-content/uploads/2019/01/Joint-Non-Paper-LGBTI-signed.pdf. Viitattu 25.4.2020.

Tiilikainen, Teija. 2003a. The Finnish Presidency of 1999. Pragmatism and the promotion of Finland's position in Europe. Teoksessa Ole Elgström (toim.), European Union Council Presidencies. A Comparative Perspective. Lontoo ja New York: Routledge, 104-119.

Tiilikainen, Teija. 2003b. Finland: smooth adaptation to European values and institutions. Teoksessa Wolfgang Wessels, Andreas Maurer ja Jürgen Mittag (toim.), Fifteen into one? The European Union and its Member States, Manchester: Manchester University Press, 150-165.

Tuominen, Hanna. 2020. Suomi ja EU:n yhteinen turvapaikkapolitiikka - ulkorajalla vaan ei ulkoradalla. Teoksessa Kimmo Elo (toim.), Suomi 25 vuotta EU:ssa. Turun Eurooppa-foorumin julkaisu 8/2020, 49-55. https://issuu.com/turun_yliopisto/docs/suomi-25-vuotta-eussa. Viitattu 19.11.2020.

Tuominen, Hanna ja Nyyssönen Heino. 2019. Eurooppalainen identiteetti populismin paineessa. Kosmopolis 49:2, 24-41.

UM. 2019. Agenda for Action on Business and Human Rights, 2.12.2019. https://um.fi/documents/35732/0/ Agenda+for+Action+on+Business+and+Human+Rights+02122019.pdf/54eb2f6f-04a5-3060-7377e6fcd4847121? $\mathrm{t}=1575292990419$. Viitattu 22.5.2020.

Vandecasteele, Bruno ja Bossuyt Fabienne. 2014. Assessing EU council presidencies: (Conditions for) success and influence. Comparative European Politics 12:2, 233-247.

https://doi.org/10.1057/cep.2013.1

VN. 2019a. Osallistava ja osaava Suomi - sosiaalisesti, taloudellisesti ja ekologisesti kestävä yhteiskunta. Pääministeri Rinteen/Marinin hallitusohjelma 2019. https://valtioneuvosto.fi/rinteen-hallitus/hallitusohjelma. Viitattu 19.11.2020.

VN. 2019b. EU-ministerivaliokunta käsitteli EU:n tulevaa strategista ohjelmaa (tiedote 8.5.2019). https:// valtioneuvosto.fi/artikkeli/-/asset_publisher/10616/eu-ministerivaliokunta-kasitteli-eu-n-tulevaastrategista-ohjelmaa . Viitattu 19.11.2020.

VN. 2019c. Hallitusneuvottelujen 2019 materiaalit. https://valtioneuvosto.fi/hallitusneuvottelut. Viitattu 22.4.2020.

VN. 2020. Suomi tasa-arvon kärkimaaksi. Hallituksen tasa-arvo-ohjelma 2020-2023, 25.6.2020. https://valtioneuvosto.fi/documents/1271139/20825107/Valtioneuvoston_periaatep\% C3\%A4\%C3\%A4t\%C3\%B6s_hallituksen_tasa-arvo-ohjelma_2020-2023\%2B.pdf. Viitattu 19.11.2020.

VNK. 2009. Valtioneuvoston selonteko EU-politiikasta 2009. https://vnk.fi/documents/10616/622958/ J1609_Valtioneuvoston+selonteko+EU-politiikasta.pdf. Viitattu 19.11.2020.

VNK. 2013. Valtioneuvoston selonteko EU-politiikasta 2013. https://vm.fi/julkaisu?pubid=1703. Viitattu 19.11.2020.

VNK. 2017. Valtioneuvoston EU-vaikuttamisstrategia 2018. https://vnk.fi/documents/10600/5781461/ 
Valtioneuvoston+EU-vaikuttamisstrategia $+2018 / 562582 \mathrm{~d} 0-8411-4 \mathrm{f} 70-9 \mathrm{c} 68-\mathrm{e} 733194 \mathrm{cbdd} 1$ ?version=1.2 . Viitattu 19.11.2020.

VNK. 2019. Kestävä Eurooppa - kestävä tulevaisuus. Suomen EU-puheenjohtajakauden ohjelma. https:// eu2019.fi/ohjelma. Viitattu 19.11. 2020.

VNK. 2020. Suomen EU-puheenjohtajakausi 2019; Kansallisen puheenjohtajuusohjelman painopisteissä saavutettu edistys, 14.1.2020. https://vnk.fi/documents/10600/20513734/liite+1+Suomen+EU-pu heenjohtajakausi+VNEUS2020-00008.pdf/a7f58cd6-478d-74a8-5701-6be230341062. Viitattu 19.11. 2020.

Weatherill, Stephen. 2016. Law and Values in the European Union. Oxford: Oxford University Press.

Wennerström, Erik. 2020. Can the EU Protect its Fundamental Values? Teoksessa Engelbrekt A. Bakardjieva, Niklas Bremberg, Anna Michalski ja Lars Oxelheim (toim.), The European Union in a Changing World Order: Interdisciplinary European Studies. Palgrave Macmillan, 245-272.

Williams, Andrew. 2004. EU Human Rights Policy: A Study in Irony. Oxford: Oxford University Press.

Williams, Andrew. 2010. The Ethos of Europe. Values, Law and Justice in the EU. Cambridge: Cambridge University Press.

\section{KIRJOITTAJATIEDOT}

\section{HANNA TUOMINEN}

VTT, maailmanpolitiikan yliopistonlehtori

Valtiotieteellinen tiedekunta

Helsingin yliopisto

hanna.t.tuominen@helsinki.fi 


\section{LIITE: TUTKIMUKSEEN HAASTATELLUT HENKILÖT AAKKOSJÄRJESTYKSESSÄ:}

Ahokas Jussi, pääekonomisti, SOSTE ry.

Elo Simon, entinen kansanedustaja (sin.), jäsen EU-puheenjohtajuutta valmistelevassa eduskunnan työryhmässä

Finér Sonja, toiminnanjohtaja, Finnwatch

Halonen Kare, osastopäällikkö, EU-asioiden valtiosihteeri

Hassi Satu, kansanedustaja (vihr.), Suuren valiokunnan pj. 2019-, eurokansanedustaja 2004-2014

Heinilä Terhi, pääsihteeri, Naisjärjestöjen keskusliitto

Jokelainen Jaana, EU-erityisasiantuntija, Valtioneuvoston kanslia

Kanner Jussi, demokratiatuki ja dialogiasiantuntija, Demo Finland

Laajapuro Nina, ihmisoikeustyön johtaja, Suomen Amnesty

Lappalainen Rilli, vaikuttamistyön johtaja, Fingo

Lindfors Pia, toiminnanjohtaja, Pakolaisneuvonta

Mahlamäki Pirkko, pääsihteeri, Vammaisfoorumi, (myös EDF ja EWL)

Mäkelä Jani, kansanedustaja (ps.), Suuren valiokunnan varapj. 2019-, jäsen EU-puheenjohtajuutta valmistelevassa puolueiden työryhmässä

Männistö Kaisa, erityisasiantuntija (oikeudelliset ja institutionaaliset kysymykset), Suomen EU-edustusto, Bryssel

Nousiainen Katriina, erityisasiantuntija (oikeusministeriö), demokratia- ja julkisoikeusosasto, itsehallinto ja yhdenvertaisuus

Nurmenniemi Veera, vaikuttamistyön ja viestinnän vastaava, Suomen UN Women

Parviainen Olli-Poika, valtiosihteeri (sisäministeriö), hallitusneuvotteluiden Eurooppa-työryhmän vetäjä

Peltonen Anne, projektipäällikkö EU-puheenjohtajuuskauden hanke, Fingo

Pirkkala Sami, johtava asiantuntija (kestävä kehitys), valtioneuvoston kanslia

Pohjolainen Anna-Elina, erityisasiantuntija (oikeus- ja sisäasiat), Suomen EU-edustusto, Bryssel

Raevaara Eeva, neuvotteleva virkamies, sosiaali- ja terveysministeriö, tasa-arvoyksikkö

Rahunen Mia, ilmastoasiantuntija, WWF

Rinne Antti, kansanedustaja (sd.), puolueen puheenjohtaja, Suomen pääministeri 6.6. -9.12. 2019

Saramo Peter, eduskunnan EU-sihteeristön päällikkö

Satonen Arto, kansanedustaja (kok.), Suuren valiokunnan pj. 2018-19, EU-puheenjohtajuutta valmistelevan puolueiden työryhmän pj.

Sipilä Juha (kesk.), pääministeri 29.5. 2015 - 6.6. 2019

Säynäjäkangas Eero, eduskunnan Brysselin toimisto

Tarjamo Kerttu, pääsihteeri, Seta ry.

Terho Sampo, Eurooppaministeri (sin.) Sipilän hallituksessa 5.5. 2017- 6.6. 2019

Tuppurainen Tytti, Eurooppaministeri (sd.) Rinteen hallituksessa 6.6. -9.12. 2019, Eurooppa- ja omistajaohjausministeri Marinin hallituksessa 10.12.2019-

Urhonen Amu, toiminnanjohtaja, Kynnys ry.

Veistola Tapani, erityisasiantuntija, Suomen luonnonsuojeluliitto

Virkkunen Henna, europarlamentaarikko (kok.) 